\title{
BUILDING A CASTLE ON SAND: EFFECTS OF MASS PRIVATIZATION ON CAPITAL MARKET CREATION IN TRANSITION ECONOMIES
}

\section{Zuzana Fungáčová}
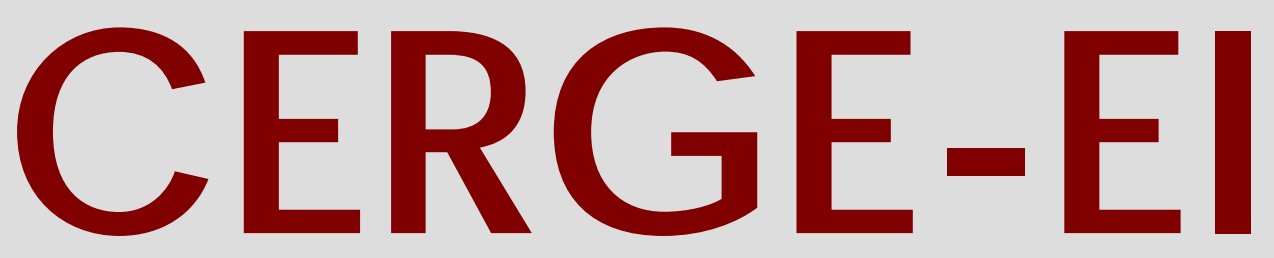

Charles University CenterforEconomic Research and Graduate Education Academy of Sciences of the Czech Republic Economic Institute 


\title{
Working Paper Series 256 (ISSN 1211-3298)
}

\section{Building a Castle on Sand: Effects of Mass Privatization on Capital Market Creation in Transition Economies}

\author{
Zuzana Fungáčová
}

CERGE-EI

Prague, April 2005 
ISBN 80-7343-050-9 (Univerzita Karlova v Praze, CERGE)

ISBN 80-7344-039-3 (Národohospodářský ústav AV ČR, Praha) 


\title{
BUILDING A CASTLE ON SAND:
}

\section{EFFECTS OF MASS PRIVATIZATION ON CAPITAL MARKET CREATION}

\section{IN TRANSITION ECONOMIES*}

\author{
Zuzana Fungáčová \\ CERGE-EI
}

\begin{abstract}
In this paper we study the relationship between mass privatization and capital market development in the transition economies. The link is investigated empirically using a panel of data which includes most of the transition countries. Our results confirm the hypothesis that mass privatization exerted a negative influence on capital market functioning in the short and medium term. Results further indicate that in countries with mass privatization, the capital market was established and perceived only as a by-product of the privatization process and did not serve as a source of capital for the corporate sector. This non-transparent market of thousands of securities caused negative investor sentiment and thus did not contribute to initiating economic growth.
\end{abstract}

\begin{abstract}
Abstrakt
V tomto článku zkoumáme vztah mezi velkou privatizací a fungováním kapitálových trhů $\mathrm{v}$ tranzitivních ekonomikách. Závislost je zkoumána empiricky pomocí panelových dat zahrnujících většinu tranzitivních ekonomik. Naše výsledky potvrzují platnost hypotézy, že velká privatizace měla negativní dopad na fungování kapitálových trhů v krátkém a středním období. Výsledky dále ukazují, že $\mathrm{v}$ zemích, které používaly při privatizaci velkých firem kupónové metody, vznikl kapitálový trh jako vedlejší produkt této privatizace a nepřinesl pro firmy nové zdroje kapitálu. Nově vzniklé netransparentní burzy s tisíci obchodovanými cennými papíry odrazovaly investory a tím pádem nepřispěly k ekonomickému růstu.
\end{abstract}

JEL Classifications: G15, G28, P34

Keywords: privatization, mass privatization, emerging capital markets, capital market

\footnotetext{
${ }^{*}$ For helpful comments and suggestions I am grateful to Randall Filer, Jan Hanousek, Evžen Kočenda and Jan Švejnar. I would also like to thank Laura Mentz for careful editing of the paper.

While working on this paper, I have benefited from GACR Grant No. 402/05/1014.

E-mail:zuzana.fungacova@cerge-ei.cz. Address for correspondence: CERGE-EI, P.O. BOX 882,

Politických vězňu 7, 11121 Prague, Czech Republic.

Center for Economic Research and Graduate Education of Charles University and Economic Institute of the Academy of Sciences of the Czech Republic.
} 


\section{Introduction}

Privatization, which enabled the transfer of state-owned enterprises to private hands, has been considered one of the keystones of the transition process in all post-communist economies and it became one of the first objectives of the newly formed governments. This objective was strongly supported especially by proponents of the Washington Consensus ${ }^{1}$, which emphasized fast transfer of ownership via privatization and faith in the market to ensure better and more efficient performance of the economy (Roland, 2001). In fact, efficiency was the most important argument for privatization as the transfer of ownership rights is crucial for the efficient allocation of resources in the economy. This way, the argument went, economic growth should be initiated. However, to achieve these objectives privatization itself is not sufficient since the functioning of a market economy requires not only private ownership but also a certain institutional framework to support the whole system. Roland (2001) in this respect stresses the experience that the "policies of liberalization, stabilization and privatization that are not grounded in adequate institutions may not deliver successful outcomes" (p.30). More specifically, Zinnes et al. (2001) argue that "privatization involving change-of-title alone is not enough to generate economic performance improvements" (p.147). Therefore, what they call "deep" privatization, including institutional and "agency"related reforms, is necessary. Unfortunately, taking into account the experience of the majority of transition countries, privatization can hardly be considered "deep". The first reason is the fact that the state tends to use certain instruments (e.g. golden shares) to maintain control over some enterprises. Thus there exists a contradiction in the way the state behaves, insofar as it initiates and supports the privatization process while at the same time exercising certain power over some companies ${ }^{2}$. This kind of discrepancy significantly slows down the transition process and may result in incomplete privatization. Secondly, the necessity for an institutional and legal framework was in many countries recognized only after the privatization process itself had begun, which

\footnotetext{
${ }^{1}$ Roland (2001) mentions that the term "Washington Consensus" was initially coined by John Williamson in 1990 and did not refer at all to transition. Since then it has been used in particular to label the thinking behind IMF and WB orthodoxy and has aroused controversy not only in the context of transition but also in the context of structural adjustment.

${ }^{2}$ See Kočenda (1999); Kočenda and Valachy (2002) for calculations and more details.
} 
led to the creation of some institutions within a very short period of time ${ }^{3}$. Consequently, the quality of the privatization process was adversely affected. Given these problems, privatization as actually conducted cannot be considered "deep" privatization in the sense defined above. An important implication is the understanding that deep privatization not only enables private ownership but at the same time influences the development of institutions (incurring "hidden" costs) and through this channel the functioning of the whole economy.

The financial sector has also been influenced by privatization. In a sense, the financial system has a unique position within a transition economy because, having performed no real function in the planned economy, it had to be developed from scratch during the transition process and thus, as Bodin and Wachtel (2002) claim, this sector is still underdeveloped compared to the overall level of economic development in transition countries. Nevertheless, the development of the financial sector was important, especially with respect to the conditions that prevailed in the transition economies at the beginning of transition ${ }^{4}$. Generally speaking, these economies suffered from undercapitalization and hence new investments were essential for enterprise restructuring because neither the underdeveloped banking sector nor domestic investors were able to provide sufficient resources. Consequently, in order to attract a sufficient amount of capital from abroad, the need for efficient capital markets in transition economies became a necessity, and their development and regulation belong to the key issues that indicate the progress of reforms.

Despite the importance of capital markets, the connection between privatization method and capital market development has not yet been well established nor sufficiently covered. Even though the positive effect of privatization on growth has been observed ${ }^{5}$, the relation between privatization method and its impact on the newly established capital markets has been neglected. Due to the large variety of privatization methods implemented (Brada, 1996), their relation to emerging capital markets also varies considerably. While privatizing state assets through the capital market contributes

\footnotetext{
${ }^{3}$ This problem was also pointed out by the World Bank Operations Evaluation Department (2004) when evaluating Economies in Transition. The OED claims that one of the two reasons why "the initial emphasis on rapid privatization to promote private sector development did not always achieve its intended effect was the lack of a supporting legal and institutional framework" (p.1).

${ }^{4}$ For a more detailed description see e.g. Estrin and Stone (1997).

${ }^{5}$ For more details see e.g. Bennett et al. (2004).
} 
positively to its functioning, direct sales of state assets in fact do not affect capital markets, at least not at the time of sale $^{6}$. On the other hand, by the administrative decision of putting shares of all privatized companies on the market, mass privatization programs tended to ignore the standard listing requirements and suppressed the traditional concept of capital market development. It was incorrectly assumed that more publicly traded companies would generate a more liquid market. Such an artificial approach led to problems with capital market development, and the affected markets fell behind those, which had evolved gradually, in a more standard way. Hence, the functioning of capital markets in mass privatization countries would seem to lag the development of other transition economies, which we consider to be the price for establishing capital markets only as a kind of "by-product" of mass privatization.

The primary objective of this research, therefore, is to empirically investigate the connection between the privatization method implemented and the consequent capital market $^{7}$ development. Considering the whole transition process with an emphasis on the country's institutional setting and legal framework will, based on our conjecture, reveal costs implied by mass privatization with respect to capital market creation. The most important task is not only to describe the situation in transition countries but to check and confirm the presence of the influence of privatization on capital market in the available data.

The following section provides motivation for our work. Section 3 discusses the privatization process in transition countries, section 4 provides an overview of capital market development in these countries and section 5 examines mass privatization in connection to capital market emergence and development. In sections 6 and 7 we discuss the data used, specifications of estimated equations, results and their interpretation. Section 8 concludes.

\footnotetext{
${ }^{6}$ Later on, when the privatized companies grow, they can use capital market as one of the sources of capital (through IPOs) and this way fuel their operations.

7 This research focuses on the equity market as the most important component of capital market in connection to the privatization process. Moreover, in comparison to equity, there are relatively few corporate bonds in transition economies (EBRD, 1998), even though debt markets for government securities tend to develop in a relatively standard way.
} 


\section{Motivation}

Investigation of the possible relationship between privatization method and capital market emergence is important not only in the context of the economics of transition but also for the long-term development of these countries because capital markets in general provide an important source of financing viable investment projects and thus initiate further economic growth. Empirical studies of King and Levine (1993), Levine and Zervos (1998), Rousseau and Wachtel (2000), Beck and Levine (2004) also confirm this relationship and provide evidence of a positive correlation between stock market development and economic growth. Levine and Zervos (1998) use data on 47 countries (1976 - 1993) to show that stock market liquidity and banking development are positively correlated with contemporaneous and future rates of economic growth, capital accumulation, and productivity growth. Rousseau and Wachtel (2000), by employing panel techniques, find that deep and liquid equity markets have had a significant and persistent impact on economic performance. They indicate that stock markets promote economic development by providing investors with a potential exit mechanism, offering liquidity to investors that encourages diversification, supplying firms with access to permanent capital and generating information about the quality of potential investments. Beck and Levine (2004) apply generalized-method-of-moments techniques developed for dynamic panels. They show that stock markets and banks positively influence economic growth and that these findings are not due to potential biases induced by simultaneity, omitted variables or unobserved country-specific effects. Positive influence of capital markets on growth holds true even for bank-driven financial systems prevailing in transition countries. As Korhonen et al. (2000) argue capital markets in both market-based as well as bank-driven systems provide economic agents with valuable information about prices in the economy and offer a means of reallocating risks. Therefore, their importance within the financial system should not be neglected by policy makers in transition countries.

In the context of capital market development another important stream of empirical literature examines the institutional framework, including the legal system, as a major determinant of financial development (La Porta et al. 1997, 1998, 2000; Demirguc-Kunt and Maksimovic, 1998). These studies emphasize the importance of the rights of minority shareholders as well as creditors. Better legal systems in this respect 
ensure a safer environment for investors, meaning that the financial sector can develop much faster. However, good legal systems are necessary but not sufficient, because as Pistor et al. (2000) stress, a persistent obstacle towards greater financial development is the lack of enforcement of existing laws.

An important role that well-developed capital markets play concerns the possibility to prevent crisis in the banking system if a credit crunch occurs. In such a case capital markets can help fill the ensuing funding gap and thus the "existence of multiple avenues of financial intermediation" can be important in preventing financial crises from causing sustained knock-on effects on the real economy (Wagner \& Iakova, 2001). In this respect Davis (2001) finds empirical evidence that the existence of active securities markets alongside banks is beneficial for the stability of corporate financing. However, in this case it is also necessary to take into account the other side of the coin, which is the possibility of capital markets contributing to financial crisis, especially if they become too liberalized and vulnerable to global shocks.

All in all, a country's financial development is closely related to its institutional and legal framework and, furthermore, this development is also one of the factors fostering economic growth. This area of research has shown what a crucial role policies play in supporting the development of financial intermediaries and markets. Nevertheless, we need to be careful in applying these considerations to transition countries, since all of the above-indicated standard and well established relationships may not hold as strongly and straightforwardly as in the developed economies since the transformation process in transition economies has not yet been completed. This view is supported by Berglof and Bolton (2003), who examine the experience of financial transition based on the ratio of domestic credit to GDP being a measure of financial development. They argue that the link between financial development and economic growth does not appear to be very strong during the first decade of transition. Nevertheless, the findings of a recent study by Bennett et al. (2004) which investigates the impact of differences in privatization and in private sector and capital market development on economic growth in transition economies during the time period from 1991 to 2001 confirm a significant positive impact of stock market development on growth.

Although in the context of transition the aforementioned relationships are at present not all that persuasive, the real functioning of capital markets is of vital 
importance for all transition economies. In the course of the transition process these markets facilitate allocation of property rights either after the initial distribution of vouchers in a mass privatization or in the case of the sale of state assets through direct share offerings (World Bank, 1996). Furthermore, despite strong internationalization pressures and the possibility of listing securities abroad, these markets are expected to serve as a source of capital for the expanding medium-sized companies (Bakker \& Gross, 2004) that are crucial for economic growth. However, Bakker and Gross further emphasize that they do not expect small stock exchanges in transition countries to survive on their own but rather to enter into strategic partnerships with other exchanges. On the other hand, larger companies have an advantage because of the possibility to enter markets abroad, in comparison to smaller enterprises that suffer from various constraints (Lizal \& Švejnar, 2001) and therefore have to rely on the functioning local capital markets. The need for efficient capital markets in transition economies is thus essential and should be considered a main policy priority.

\section{Privatization process in transition economies}

A majority of studies concerning transition countries indicates that the overall impact of privatization on the functioning of these economies was positive (Djankov and Murrell, $2002)^{8}$. Yet, even though various impact channels are examined in these studies, care needs to be taken when interpreting their results. As Stiglitz (1999) points out, means and ends are often mixed together here. The main objective of privatization is to attain efficiency in the economy and to initiate sustainable economic growth. Hence privatization serves as a mean to these ends. However, in a broader sense even the creation of a market economy can be a means to sustainable development. If this kind of interpretation is considered, Stiglitz argues that the success of market-oriented reform is more mixed. On the other hand, private property is undoubtedly one of the key inputs in the standard model of a market economy and thus privatization, despite certain doubts and controversies concerning the whole process, is necessary.

The privatization process itself depends on several crucial factors that are of importance for this study as well. In general, the chosen privatization method plays a

\footnotetext{
${ }^{8}$ The results showing mostly positive impact of privatization on transition economies have recently been challenged by Hanousek, Kočenda, and Švejnar (2004).
} 
key role (World Bank, 1996). Even the sequencing of the whole process becomes very important (Gupta, Ham and Švejnar, 2000). In the context of transition countries, at every phase of the privatization process, crucial decisions were taken by the state authorities; privatization is therefore considered to be exogenous ${ }^{9}$. The decisions of these authorities differed and thus, as Table A.2 in the appendix indicates, the privatization process has exhibited a large degree of variability as each transition economy has pursued its individual strategy (World Bank, 2002). The table also illustrates the importance of the voucher method as primary as well as secondary method of privatization. But differences among countries do not concern only the methods implemented. Variability also arises from the different initial conditions, political backgrounds, and other country specific factors, as well as the speed, sequencing, and timing of the privatization in the context of the whole transition process.

The World Bank report assessing the first ten years of transition (2002), stresses that the ideal privatization strategy leading to the best after-privatization performance of companies would have been to transfer assets as rapidly as possible to individual investors or concentrated groups of strategic investors through open, fair and transparent methods. Unfortunately, such a procedure was not possible to implement in many countries given certain country specific characteristics, especially those of a political nature (Biais \& Perotti, 2002). In this respect, the argument of equal distribution was very strong especially in the countries where voucher privatization played a significant role. Besides these characteristics, the gains in economic efficiency or necessary government revenues from privatization were crucial (Gupta, Ham and Švejnar, 2000). Accordingly, the designers of privatization mainly considered the speed of the ownership transfer together with economic and political issues important at that time, but did not accurately estimate or even take into account the possible future consequences of employing a certain privatization method.

In general, privatization was one of the first reform steps undertaken in the transition process and different privatization methods tended to affect the development of emerging capital markets in different ways.

\footnotetext{
${ }^{9}$ Exogenous here means the decision about privatization and its timing with respect to the capital market. Clearly, the privatization decision is not a function of the capital market.
} 
- SMALL SCALE PRIVATIZATION concerned small and medium enterprises privatized by implementing particularly simple auctions at the beginning of the transition process. In this respect, small-scale privatization is considered to be one of what the EBRD transition report (2003) considers initial phase reforms, which are more straightforward and relatively easier to implement ${ }^{10}$. And true enough, this level of privatization has been for the most part successful, and the majority of transition countries have managed to conclude it relatively quickly. Yet from our point of view it is important to note that the small-scale privatization neither initiated nor had an effect on the capital market development, since most of these firms were and stayed not large enough to be able to participate there.

- THE SALE OF STATE PROPERTY (case-by-case privatization) concerns primarily large and strategic enterprises, and has not yet been completed. Case-by-case privatization can take the form of direct sales or share issue privatization, similar to initial public offerings in the private sector (Brada, 1996). State property is sold directly to the new owner, who can be domestic as well as foreign. According to EBRD (2003), this privatization method belongs to the category of so-called second phase reforms, which are more complex and take longer to implement as they require the development of market-based structures and institutions, including a capital market. In this respect, case-by-case privatization influenced capital market greatly. However, in this case capital markets tend to emerge gradually and originate through voluntary IPOs, which themselves are either initiated by share issue privatization or by firms already acquired by new owners who are searching for additional capital resources, since the supply of capital for restructuring from other sources is limited ${ }^{11}$. Conditions in the economy thus require the existence of a capital market, and allow it to develop in a standard way.

- MASS PRIVATIZATION was considered an appropriate privatization method especially with respect to the conditions that prevailed in transition countries at the beginning of the transition process ${ }^{12}$. Further, its social and political acceptability

\footnotetext{
${ }^{10}$ The World Bank (1996) also stresses that small assets are easier to privatize than larger enterprises and that positive outcome in the former category are relatively assured.

${ }^{11}$ In this respect the role of banks in the economy is important. Whereas in the Czech Republic companies were able to obtain loans from a bank relatively easily (soft budget constraint), in Hungary it was quite difficult to obtain resources from a bank and therefore the capital market development was initiated from the inside.

12 This basically concerns undercapitalization and the lack of foreign investors' interest to invest in these economies. This issue has already been discussed in the introduction.
} 
followed from the equal distribution of shares as well as from the fact that citizens incorrectly perceived income from privatization to be net profit for them. The BarroRicardian equivalence was hence not valid, which gave the authorities a chance to "bribe" people and gain their support for mass privatization (Hanousek and Tůma, 1997).

All in all mass privatization was, in different forms and modifications, included as a part of the privatization program in 21 out of 27 transition economies. Still, the proportion of formerly state owned assets privatized using this method differed considerably among them. Table A.3 in the appendix illustrates the different variations of mass privatization that were implemented ${ }^{13}$. The first countries to implement mass privatization already at the beginning of the 1990s were Russia and the former Czechoslovakia. They later served as a model for other countries (e.g. Bulgaria's first wave of mass privatization followed the Czech model: for more details see Table A.4 in the appendix). However, the relatively high number of mass privatization models that are presented in the table also suggests that the diversity of ways in which privatization was implemented has also had a further impact on the outcomes of the whole transition process. Nevertheless, the way voucher privatization was conducted led to only a formal change of ownership from the state to a large number of uninformed shareholders who had no experience managing these kinds of assets. In essence, this means that the ineffectiveness connected to the state as an owner was in fact just transferred to a group of new owners who could be considered "quasi-owners," and who did not think strategically and whose planning horizon was relatively short. As the World Bank (1996) points out, these owners were survival-oriented, focused only on sustaining current cash flow. Since the immediate liquidation value of such companies was often higher than the net present value of future investments (Lízal and Švejnar, 2001) it was more profitable for these "quasi-owners" to "tunnel" the company and use its assets to make themselves better off.

Given the way it was conducted, then, voucher privatization cannot be considered "deep" privatization in the sense defined above. It brought about serious problems that were either dismissed as only temporary (and were believed capable of

${ }^{13}$ Some countries provided equal access to all citizens while in others there were significant concessions provided to insiders: Russia, Moldova, Georgia, Armenia (for more details see EBRD Transition Report 1997). This fact has also influenced trading with shares after the privatization. 
being solved by the power of the market ${ }^{14}$ ) or that were not accounted for when privatization was undertaken. Voucher privatization failed to generate the new capital necessary to restructure companies strategically, or to concentrate ownership. Its implementation is thus still subject to debate. Nevertheless, it is important to note that voucher privatization would not necessarily have been unwise or inappropriate, if its natural continuation had been recognized and implemented. The World Bank report assessing the first ten years of transition (2002), for instance, points out that mass voucher privatization in the former Czechoslovakia would have had a better chance of producing more restructuring and less corruption if the legal framework governing companies, investment funds, and capital market activities had been enforced from the very beginning. That other transition countries where mass privatization was a dominant privatization method suffered from similar weaknesses in the way this procedure was implemented would indicate that the success of mass privatization required a transparent and appropriately regulated capital market with minority shareholders' protection and active corporate governance (Hanousek and Kočenda, 2003). If these conditions had been set up properly in the immediate aftermath of voucher privatization, the results of the overall privatization process would have been far more satisfactory. The failure to set up these conditions and even more to the point the failure to recognize the impact of privatization on the capital market, naturally precluded a more satisfactory outcome to the privatization process.

\section{Capital markets in transition economies}

\subsection{Factors determining the emergence of capital markets}

Before investigating the role of privatization in capital market development, we first briefly examine the phenomenon of capital market emergence in transition economies. This issue is of particular importance because capital markets are, even today, not yet properly functioning and in comparison to their western counterparts relatively unimportant for the domestic economies in all these countries ${ }^{15}$. Therefore, it is useful for policy makers to know which forces make capital market operate. Whether a capital

\footnotetext{
${ }^{14}$ Mutual privatization funds were expected to contribute to active corporate governance after the shares of formerly state enterprises were distributed in mass privatization.

${ }^{15}$ For more details see Wagner and Iakova (2001), Bodin and Wachtel (2002), Köke and Schröder (2002), EBRD Transition Report 2003 as well as law-oriented literature e.g. Ahdieh (2003).
} 
market in a certain country exists is determined by a large variety of factors, many of them having a connection to economic growth; in the context of transition economies privatization, macroeconomic stabilization, and the regulatory environment are of particular importance (EBRD 1998).

Initial conditions prevailing at the beginning of the transition process concern a lot of aspects and therefore it is difficult to measure them succinctly. They affect the economic performance in transition countries (De Melo et al., 1997; Berg et al., 1999; Fischer and Sahay, 2000; Falcetti et al., 2001) and can to certain extent influence capital market emergence as well. The process of capital market creation is relatively easier for countries that already have a certain tradition and experience with its functioning: that is, that it had existed in that country before communism ${ }^{16}$.

Nevertheless, as has already been discussed earlier, the privatization process undoubtedly plays a role here. Based on the EBRD Transition Report 1995 the development of the securities markets in transition countries "has so far been largely shaped by the nature of privatization programs" (p.164). Not only do certain privatization methods require the immediate existence of a capital market but they also determine the post-privatization ownership structure. Based on this structure further trading evolves, and in this way privatization method becomes a mechanism that predetermines the functioning of an emerging capital market.

Related studies concerning capital market development (King and Levine, 1993; La Porta et al., 1997; Henry, 2000) provide evidence that the most crucial factors influencing capital markets include the macroeconomic environment and institutional arrangements in the economy. With increasing income per capita individuals tend to have more resources available to invest on the capital market and this undoubtedly contributes to its development. As Garcia and Giorgio (2003) note, there is a tendency for the share of equity markets to increase relative to banking markets as per capita income increases. Another related variable is the level of public debt in the economy, since the higher level of debt can to a certain extent cause crowding out of the private sector from the capital market. Moreover, the empirical evidence shows that inflation negatively influences capital market.

${ }^{16}$ EBRD Transition Report 1995 also notes that the formation of securities markets began in 1990-91with the reestablishment of exchanges in Bulgaria, Croatia, Hungary, Poland and Slovenia. Then in 1993 the Prague Stock Exchange was reopened. 
The role of institutions and appropriate legal environment in the transition process has already been pointed out as well. According to Ahdieh (2003), law scholars have identified, at most, an indirect role for law in the market transition process. This role basically concerns creating a framework within which securities markets will spontaneously emerge. It includes clear property rights, provision of reliable contract enforcement and more recently the protection of minority investors. Pistor (2000) argues that these are necessary but not sufficient conditions for healthy capital market development because what seems to matter most in transition economies is the actual enforcement of law.

The development of capital markets may be slowed down if there are other strong financial intermediaries in the economy, namely banks providing enterprises with sufficient credit. Yet empirical evidence (King and Levine, 1993; Levine and Zevros; 1995) shows that the effect of banks and the effect of the capital market do not eliminate each other, and that both do contribute to economic growth. Thus, if both of these financial intermediaries function well, raising capital for investments is more efficient and this naturally stimulates economic growth. Nevertheless, banks may continue to be favored due to tradition and also because capital markets generally require more sophisticated investors making decisions about their portfolios. In spite of their preferred position, however, banks depend on progress made in the financial system and in banking reform, both of which are inseparable parts of the transition process. And as Table A.5 in the appendix indicates, financial system reform has not progressed far enough in all the transition economies.

The influence of these factors on developing capital markets has already been discussed in the relevant literature. The exception seems to be the privatization method and its implementation which, we conjecture, has played a key role in capital market formation. This conjecture has not been sufficiently addressed so far. 


\subsection{Development of capital markets}

Given the above-suggested connection between privatization and capital markets, the success of transition reforms ${ }^{17}$ is questionable also with respect to the functioning of capital markets. This is partly the result of insufficient reforms and partly due to the fact that even though certain laws and regulations have been enacted, it takes time to implement and enforce them and to observe any positive results connected to the changes in legislation. Therefore, as EBRD Transition Report 2003 reports, even though improvements in the legal and regulatory framework for pension funds, growing transparency, and efficiency and sophistication of the securities market have been observed recently (especially in Russia, Serbia and Montenegro and Slovakia), the overall state of the financial sector in the transition economies is still considered underdeveloped.

As to the development of the financial sector, capital markets have followed different patterns in transition countries. In comparison to other structures of the market economy, their creation is more complicated because there is a need to support the institutional infrastructure and regulatory mechanisms as well (Bodin and Wachtel, 2002). However, this need was not sufficiently taken into account in some countries ${ }^{18}$.

Capital market development mainly started from scratch despite the fact that some of these markets were actually reestablished after several decades. Capital markets emerged at different stages of the transition process. Some of them officially started in the early 1990s. This first group includes countries where mass privatization was not implemented as a primary method: Slovenia (1990), Hungary (1990) and Poland (1991). Then, in 1993 stock exchanges in the Czech Republic, Slovakia and Lithuania followed, all of them connected to the mass privatization program. Other stock exchanges were established later on in the mid-1990s (Romania, Latvia, Estonia) but there are still several transition countries where capital markets in fact do not exist ${ }^{19}$. Yet another distinct feature in transition capital market development is the impetus for their creation.

\footnotetext{
${ }^{17}$ It should be noted that the privatization of strategic enterprises as well as other aspects of the transition process have yet to be completed. EBRD Transition report (2003) notes that even in the most advanced countries of Central Eastern Europe and the Baltics (CEB) that became members of the EU, reforms have to continue. This mainly concerns the breadth and depth of these countries' financial markets and the restructuring of strategic sectors such as energy, heavy industry and agriculture.

${ }^{18}$ A good example would be the creation of SEC in the Czech Republic only in 1998, five years after trading at the Prague Stock Exchange started.

${ }^{19}$ Here we refer to de facto existence, not de jure. This concerns Albania, Turkmenistan, Tajikistan.
} 
While in some countries their formation was an inseparable part of the transformation strategy and was, together with the framework for security trading, planned well in advance (this concerns the first group of countries mentioned above), there are other instances where this was not the case and capital markets emerged only because they were necessary to supplement other reforms, most often mass privatization. This has consequences for the way these markets developed. The "planned" ones grew gradually with a clear upward sloping trend, despite certain volatility. The others experienced a kind of overheating during the first years of their existence, then encountered significant problems and in fact had to start over again at the end of the 1990s (see Figure 1 in the appendix).

The emerging capital markets of transition countries hence still do not perform their primary economic function and are rarely used as a source of finance for the corporate sector (Wagner and Iakova, 2001). These markets are in general characterized by low liquidity because only a few securities of the most important companies are usually traded frequently enough on each market (Wagner and Iakova, 2001; Bodin and Wachtel, 2002; Bakker and Gross, 2004). Such a situation naturally results in more expensive financing possibilities for companies and thus this source of finance is seldom used. Yet another indicator describing capital market functioning is market capitalization relative to GDP, which is despite its high levels following mass privatization relatively $\operatorname{low}^{20}$ in transition economies. As Table A.6 in the appendix illustrates $^{21}$, even though the two best performing countries (Estonia: $30.43 \%$, Czech Republic: $22.36 \%$ ) reach the values characteristic for other emerging markets (e.g. Argentina: $27.7 \%$, Brazil: $25.65 \%$, Mexico: 27.12\%), they are still significantly behind the market capitalization to GDP figures for the developed markets (e.g. United Kingdom: $131.69 \%$, United States: $105.9 \%$, or EMU markets: $44.56 \%$ ). Moreover, as the ECB report concerning financial sectors of EU accession countries (2002) observes, given the relatively low levels of GDP per capita, market capitalization in absolute terms is particularly low.

The indicators of capital market liquidity give nearly the same picture. When considering the value of stocks traded (as \% of GDP), the best performing transition

\footnotetext{
${ }^{20}$ Table 2 (see section 6) shows that based on our data set its average stands at about $10 \%$.

${ }^{21}$ All figures in this table are averages for individual countries corresponding to available data for the period $1989-2003$.
} 
economies (Hungary: 10.11\% and Estonia: 9.99\%) are comparable with other emerging markets (Brazil: 11.59\% and Mexico: 9.16\%), however they are far behind the developed economies (United States: 124.1\%, United Kingdom: 70.42\%). Turnover ratio indicator values are somewhat better, especially for the top transition economies (Slovakia: $99.89 \%$ and Poland: $69.77 \%)^{22}$ as they are already close to some of the developed markets (EMU: 103.16\%, United Kingdom: 64.16\%). However, this holds true only for these two transition economies: the others have still a long way to go to catch up with developed markets.

Further general characteristics of transition capital markets include insufficient regulation, institutional fragility or weak minority shareholder protection. All of these problems are connected to the legal and institutional framework, which in most cases did not exist when stock markets were established (EBRD 1998; Bonin and Wachtel, 2002) and which is still not sufficiently developed nor functioning well. The problem in this respect is twofold: not only is a certain time needed to make such a framework operational but the simple copying of institutions that are functioning successfully in developed economies is not sufficient to guarantee success. Hanousek and Filer (1997) in this respect stress that lack of experience combined with legal and regulatory uncertainty can result in institutions failing to perform their roles efficiently. On the other hand, especially in those countries accessing the EU, the necessary legislation has already been enacted and thus the legal environment is expected to improve. However, the enforcement of these new rules also requires a certain period of time, and the positive impact of this legislation is still not clearly visible.

Even though capital market development in the transition countries has not been too favorable so far, and even though markets tend to be inefficient, illiquid and unreliable, there are still possibilities to improve the situation, especially thanks to the pension system reforms that have been gradually implemented or are under consideration in most of the transition economies. Institutional investors are expected to play a significant role in the new pension systems and thus contribute to greater liquidity and turnover on the stock exchanges (Wagner and Iakova, 2001). Moreover,

${ }^{22}$ Even though, as Table A.6 in the appendix shows, the highest turnover ratio corresponds to FYR Macedonia, we do not consider it in our comparative analyses because there are only a few observations available for this country (3) and this is not enough to get a true picture of the situation on the market. 
pension reform is also supposed to spur the demand for domestic securities: but in this respect the lack of securities in which investors would be willing to invest creates a significant obstacle (most of the emerging markets have only a few such securities). Yet another means of boosting the performance of transition capital markets is the option that most governments in these countries still possess - to privatize residual state ownership in strategic companies through the capital market and to attract potential investors in this way.

Despite all of the above-mentioned problems, trading is now becoming more frequent, especially in those countries that have accessed EU and thus are more attractive for foreign investors. Additionally, a trend towards integration among stock exchanges ${ }^{23}$ contributes to the simplification of trading and offering a larger portfolio of products for potential investors.

\section{Mass privatization and capital market development}

Privatization methods in transition countries were rarely driven by the objective of developing a modern capital market (EBRD Transition Report, 1997). Yet despite this fact, capital market development per se in transition countries indicates a possible connection between the privatization method employed and the consequent capital market functioning, something which has not been considered in the recent literature dealing with the emergence and development of stock markets in transition economies. One important study that at least recognizes the importance of institutions and law is that by Claessens et al. $(2000)^{24}$. Examining 20 transition economies, they distinguish three sources of stock market origins: mandatory listing following mass privatization, voluntary initial public offerings (IPOs), and mandatory listing of minority packages (Table 1).

\footnotetext{
${ }^{23}$ Estonian, Latvian and Lithuanian stock exchanges are already part of the OMX group together with the Stockholm and Helsinki stock exchanges, and a merger with the Copenhagen has already been agreed on. ${ }^{24}$ It was followed by several papers (Pajuste, 2002; Bonin and Wachtel, 2002; Claessens et al., 2003; Berglof and Bolton, 2003) which strongly relied on its findings and extended them in different directions concerning financial system architecture, corporate governance, or European integration.
} 
Table 1: Sources of stock market origins

\begin{tabular}{|c||c||c|}
\hline $\begin{array}{c}\text { Mandatory listing } \\
\text { after mass } \\
\text { privatization }\end{array}$ & $\begin{array}{c}\text { Voluntary initial } \\
\text { public offerings }\end{array}$ & $\begin{array}{c}\text { Mandatory listing of } \\
\text { minority packages } \\
\text { during privatization }\end{array}$ \\
\hline \hline $\begin{array}{c}\text { Bulgaria } \\
\text { Czech Republic }\end{array}$ & Croatia & Armenia \\
FYR Macedonia & Estonia & Azerbaijan \\
Lithuania & Hungary & Kazakhstan \\
Moldova & Latvia & Kyrgyz Republic \\
Romania & Poland & Poland \\
Slovakia & Slovenia & Russia \\
& & Ukraine \\
& & Uzbekistan \\
\hline
\end{tabular}

Source: Claessens S., Djankov S., Klingebiel D. (2000): "Stock Markets in Transition Economies," Financial Sector Discussion Paper No.5, The World Bank.

The authors further assess the development of stock markets using different indicators and conclude that these markets are underdeveloped in comparison to those in industrial countries, and that the basic financial sector infrastructure is often missing. An empirical analysis based on a regression model highlights the importance of mild inflation, good shareholder protection, and institutional investor assets for the development of stock markets in transition economies. However, the influence of privatization is not taken into account.

If one considers mandatory listing of minority packages a special case of mandatory listing, even the above-mentioned classification can fit into the general pattern of two basic approaches through which capital markets can be created: so-called top-down (government-led) and bottom-up (market-led) (Simoneti, 1997). In the topdown approach the government takes the initiative (World Bank, 1996) and the necessary laws and regulations are prepared before the actual trading starts. The development begins at the high end of the market; hence there is only a small number of high quality stocks traded at the beginning. These securities are offered in traditional voluntary IPOs on the stock exchange, and trading with them tends to be fairly liquid. Later, when the market develops, the number of stocks traded also grows. This kind of capital market creation dominated in countries where there was no mandatory listing of securities in the aftermath of privatization (e.g. Hungary) or where capital markets were created well before the actual mass privatization began (Poland). In fact, capital markets without mandatory listing typically develop because the conditions in the economy already require it, as the supply of capital for restructuring from other sources is 
limited $^{25}$. Nonetheless, this approach also has its shortcomings in that there is a risk of overregulation; in this way the market's true needs might not be accounted for, as is the case in Albania (World Bank, 1996) where the capital market de facto has not worked so far.

On the other hand, under the bottom-up approach, supply and demand form the rules that govern the market since there are no, or only minimal, regulations set up before trading on these market commences. More effective rules and institutions tend to develop this way (World Bank, 1996) but the disadvantage is the existence of the unregulated market before the actual rules are set. This situation is typical for economies where stocks were mandatory listed following mass privatization, which was implemented in various modifications (see Tables A.3 and A.4 in the appendix). The natural outcome of such a privatization is a large number of stocks that are listed on the stock exchange under minimal regulations. Such markets were required to enable quick ownership transformation and thus the development of a capital market is nearly spontaneous, being only a response to the trading needs generated by privatization (Fine and Karlova, 1998). Taking this statement to extremes, it is possible to consider capital markets a kind of "by-product" of mass privatization.

Within the bottom-up approach Simoneti (1997) distinguishes two situations. In the first one, stocks of all companies are traded on the public market; in order to enable this, minimal regulatory standards are set (Czech Republic, Slovakia). Gradually, as regulation becomes stronger, some companies can no longer manage to fulfill these requirements and thus have to leave the public market. The second situation materializes when a certain limited number of securities is traded publicly and are subject to strict regulation, while the rest remain "quasi-public" and are subject to relatively weak regulation (e.g. Slovenia). This so-called dual approach enables the capital market to develop simultaneously at the high and low end of the market.

The two main approaches to capital market creation further relate to the privatization method implemented in certain countries (Table A.2 in the appendix). However, as there are different modifications of privatization methods, capital market creation can also be difficult to classify into one of the above-mentioned categories. In

\footnotetext{
${ }^{25}$ In this respect the role of banks in the economy is important. Whereas in the Czech Republic companies were able to obtain loan from a bank relatively easily (soft budget constraint), in Hungary it was quite difficult to obtain resources from a bank and therefore the capital market development was pushed from the inside.
} 
more general terms, Fine and Karlova (1998) ascribe the distinct path of capital market development to the following factors: the design of the privatization program in individual countries, the degree of capital market development at the beginning of the program, and different approaches to capital market regulation. Moreover, the availability of other sources of capital in addition to the capital market also plays an important role.

This section thus suggests the important role that the privatization process has played in the process of capital market formation in transition countries. This is the phenomenon that we investigate empirically as well.

\section{Data}

Our goal is to examine the different paths of capital market development in transition countries with respect to the privatization method implemented. In order to investigate whether and to what extent the privatization methods in these economies influenced the actual emergence and development of their capital markets, we look at a sample of the former communist countries. Altogether there are 27 states in Central and Eastern Europe and Central Asia considered to be transition economies; the majority of them is included in our sample ${ }^{26}$.

The time period under consideration covers the whole transition period, from 1990 to 2003, though this varies across countries and thus only an unbalanced panel data set is available. Moreover, not all transition countries have proceeded far enough in the transition process to make it possible to investigate the aforementioned link there. The problem basically concerns the actual emergence of a capital market. Therefore this unbalanced panel is the result of "true" missing values as well as observations that cannot be available due to the non-existence of a capital market ${ }^{27}$.

Yet another problem causing unbalanced panel to emerge is the quality of the available data. Even though there exist data for certain countries, one has to be careful to examine the data before using them and, if necessary, to "clean" them for further

\footnotetext{
${ }^{26}$ However, it is not possible to include all of the transition countries, as the relevant data are not available in all cases. The list of countries and variables actually covered is provided in the appendix (Table A.1).

27 We do not assign a "zero" value for those countries where the stock market did not exist at the beginning of transition because such an approach would result in an artificially balanced panel. Even though this would not change the estimated coefficients, t-statistics could be affected significantly and through them the results of the whole hypothesis testing.
} 
estimations. Such "cleaning" is needed because the nature of transition economies leads to observations that cannot be included in the data set and therefore we in fact need to distinguish between functioning of capital market "de jure" and "de facto". It is unfortunately not possible to distinguish because it is not possible to stipulate exact rules based on which we could decide as the situation needs to be investigated taking the country specific environment into account. In our case, the estimation results may be easily spoiled by growth rates recorded in the thousands of percent for cases when a certain newly-created stock exchange traded during a time period shorter than one year, or when it took several years before at least some trading was initiated ${ }^{28}$. Frequent organizational changes on the stock exchanges and other exogenous factors have in some instances also influenced the actual figures and thus need to be accounted for ${ }^{29}$. Yet another exogenous influence was the Russian crisis. All of these problems have been taken into account when cleaning the data and constructing the actual data set, so observations that could potentially damage the analysis have either been omitted from the data set or have been remedied by creating suitable dummy variables.

Our data come primarily from the World Development Database, available from the World Bank. Where indicated, the data set is supplemented by data from the World Federation of Exchanges as well as local stock exchange figures. Dummy variables for mass privatization are constructed based on different issues of the Transition Report published by EBRD. A brief description of the most important variables used in this study is provided in the following table ${ }^{30}$.

\footnotetext{
${ }^{28}$ This was the case, for example, in Croatia (1994, 1995 and only in 1996 did the stock exchange begin to pick up), Latvia (the stock exchange was founded in 1993, trading started in 1995, and only in 1996 did the situation stabilized to a certain extent), Lithuania (officially started trading already in 1993 but the figures are very low until 1995; in 1996 it began to stabilize), Moldova (official beginning in 1995 but trading lively only in 1997), Romania (started operation in 1995 but reasonable trading only in 1997).

${ }^{29}$ The merger of several exchanges into a new entity (Kazakhstan in 1997, Bulgaria in 1998), the decision of stock exchange authorities to list a certain group of securities that had not been listed before (Latvia in 1999), the macroeconomic development in a given country (Poland in 1993), and trading system enhancements initiated by the stock exchange and liberalization of block trading (Lithuania in 1997).

${ }^{30}$ More detailed definitions of variables together with the data sources are in Table A.7 in the appendix.
} 
Table 2: The main descriptive statistics of capital market indicators used in the analysis

\begin{tabular}{|c|c|c|c|c|c|c|c|c|c|c|}
\hline \multirow{2}{*}{ Variable } & \multirow{2}{*}{ Obs. } & \multirow{2}{*}{ Country } & \multicolumn{3}{|c|}{ Observation/country } & \multirow{2}{*}{ Mean } & \multirow{2}{*}{$\begin{array}{l}\text { Standard } \\
\text { deviation }\end{array}$} & \multirow{2}{*}{ Median } & \multirow{2}{*}{ Min } & \multirow{2}{*}{ Max } \\
\hline & & & average & $\min$ & $\max$ & & & & & \\
\hline Market capitalization to GDP & 151 & 20 & 7.55 & 2 & 13 & 10.82 & 10.66 & 7.86 & 0.004 & 53.24 \\
\hline $\begin{array}{l}\text { Growth in stocks traded } \\
(\% \text { of GDP })\end{array}$ & 102 & 17 & 6.00 & 1 & 12 & 0.59 & 2.81 & -0.06 & -0.95 & 25.05 \\
\hline Turnover ratio & 111 & 18 & 6.17 & 1 & 12 & 38.99 & 49.62 & 23.06 & 0.02 & 348.3 \\
\hline New capital raised to mar. cap. & 81 & 14 & 5.79 & 2 & 9 & 0.001 & 0.005 & $2.8 \mathrm{D}-06$ & 0 & 0.04 \\
\hline
\end{tabular}

Source: The data set used for estimations, the author's calculations

\subsection{Measures of stock market development}

We measure stock market development using the same indicators of market size and liquidity which have been used in those studies investigating development of stock markets and its connection to economic growth (Levine and Zervos, 1998; DemirgucKunt and Maksimovic, 1998; Rousseau and Wachtel, 2000; Beck and Levine, 2004). However, unlike these studies, this analysis deals with transition economies and in that context we find it important to add another measure of stock market development, new capital raised.

\section{- MARKET CAPITALIZATION}

The most frequently used indicator of capital market size is the market capitalization that reflects the total value of domestic shares listed on a certain stock exchange. Ideally, this measure shows the importance of financing through equity issues. To enable comparison among countries, market capitalization can be expressed as a percentage of GDP. However, larger markets do not have to perform better, as the size does not necessarily reflect their effectiveness. This is of particular interest especially in countries where the number of listed companies results from the implemented privatization method. Under mass privatization with mandatory stock listing, this indicator of market size can be significantly inflated because the majority of stocks that are listed are traded only occasionally, or not at all. Consequently, market capitalization does not necessarily have to reflect the real stock market activity. This problem could be solved by using data from the first tier of the market, which usually includes companies that are actually traded. However, such data are not available from all the transition economies' stock exchanges and, what's even worse, the rules for including companies in the first tier differ from country to country. Nevertheless, the market capitalization to 
GDP variable is used in our analysis to show the influence of different privatization methods on the size of the developing capital market.

\section{- LIQUIDITY MEASURES}

Happily, in contrast to the market capitalization variable, the indicators of liquidity do indeed reflect the real stock market activity, and are not "spoiled" by a high number of non-traded stocks listed on a particular stock exchange. Moreover, Rousseau and Wachtel (2000) consider increases in this measure essential especially for emerging markets, since higher liquidity raises investors' confidence in the values of information and risk diversification associated with trading, which further encourages the inflow of capital.

We employ two different measures for liquidity. The first one, market turnover ratio, can be expressed in currency units or as a share of market capitalization. Share of market capitalization reflects the value of stocks traded divided by the value of listed stocks; that is, trading relative to the size of the stock market. The second measure of market liquidity is value traded, which equals the value of trading divided by GDP. Hence, it relates the value of trading to the size of the whole economy and does not really measure the liquidity of the market (Beck and Levine, 2004). This indicator faces a potential problem, however, if prices of stocks increase because of expectations concerning higher corporate profits. In such a situation this liquidity measure, as well as market capitalization, would increase without a rise in the number of transactions, thus not reflecting the true stock market activity. To eliminate this price effect, Levine and Zervos (1998) suggest either using both capitalization and value traded together, or using turnover indicator instead. Turnover ratio is not influenced by price changes as it contains the price in both numerator and denominator. Therefore, based on the available data we primarily use this measure as an indicator of stock market development in the transition countries.

\section{- NEW CAPITAL RAISED}

Another indicator that we employ to monitor the development of capital markets in transition economies is the amount of new capital raised through a particular stock exchange. In this respect we are interested not only in capital raised by already existing companies, but primarily by newly admitted enterprises (IPOs). In most of transition economies, however, the number of IPOs was insignificant, especially in comparison to 
market capitalization. Nevertheless, we consider new capital raised very important, as it shows the real functioning of the market while fulfilling its main function of providing financial resources for enterprises. But even though this indicator may seem appropriate, one has to be aware of its possible shortcomings, namely the fact that data on new capital raised in the context of transition economies do not necessarily reflect the real situation, since not everything recorded as "new capital raised" conforms to its true definition $^{31}$. As an example could serve the problem of mergers: in some cases these were recorded as new capital raised, whereas in fact this was capital that had already existed on the stock exchange, only under a different name. Another possibility concerns changes in ISIN that could result in recording an issue with a new ISIN as new capital even though it was simply different "labeling" of this capital. In our analysis, we only use data from one source in which the above-described problems are already accounted for, although the disadvantage is that such data is available only for a limited number of countries ${ }^{32}$.

All in all, in order to investigate the development of transitional stock markets from different perspectives we employ the following variables: market capitalization to GDP; total value of stocks traded as a percentage of GDP; turnover ratio; and total amount of new capital raised as a percentage of market capitalization. We conjecture that the negative effect of privatization is going to influence different variables in a different way, based on their nature. We anticipate a sudden increase of market capitalization after mass privatization, while on the other hand stocks traded and turnover ratio as the indicators of liquidity are expected to decrease, especially over the medium term. When employing new capital raised the same pattern as for liquidity measures is expected.

Based on the above discussion, it is clear that all of these capital market indicators face some potential shortcomings. But taken together, they undoubtedly can provide a reasonable picture of capital market development tendencies in transition countries.

\footnotetext{
31 The World Federation of Exchanges defines new capital raised by shares to be the amount of new capital raised through the sale of new shares issued by a new issuer (company) through an Initial Public Offering (IPO), capital increases by already listed companies (reserved to previous shareholders), and SPOs (new shareholders subscribe the shares). This is the definition that we also adhere to.

${ }^{32}$ In this case there are 14 of them. The list of these countries is included in Table A. 1 in the appendix.
} 


\subsection{Determinants of stock market development}

As our goal is to point out and investigate the significant impact of privatization method on capital market development, the most important explanatory variable for the analysis clearly concerns privatization. The privatization method of our primary concern is mass privatization; this is accounted for by creating a dummy variable and it is considered to be exogenous. As, based on our conjecture, mass privatization exhibits a special impact on the capital market, our fundamental dummy variable only distinguishes between this and other privatization methods. The mass privatization dummy equals one, starting from the period this privatization method was implemented in a given country. Further, in order to make a finer distinction within the mass privatization group, we also differentiate between mass privatization as primary or secondary privatization method ${ }^{33}$. Even though there were multiple waves of mass privatization in some countries, it is not feasible to incorporate this into our model since implementation of more mass privatization waves was not so common in transition countries. That is, they may have been officially announced, but only a few of them were, in the end, ever conducted. Moreover, identifying two mass privatization waves is also hindered because the effect of the second wave can potentially coincide with country effects.

It is necessary, too, to account for different possible impacts of mass privatization in the estimation. Privatization can exhibit only an instantaneous effect on the capital market in the period in which it was implemented. On the other hand, its impact can be long lasting and, due to the consolidation of ownership structure, it can even evolve and become more pronounced over time ${ }^{34}$. To deal with this, we add a trend component to the mass privatization dummy and consider also a model specification with both privatization dummies (with and without trend). The implementation of privatization also requires certain length of time and thus its influence on capital market development cannot be distinguished immediately in most cases. This leads us to implement lagged privatization dummy variables. All of these extensions are further discussed when describing the estimated equations in the following section.

\footnotetext{
${ }^{33}$ This classification is based on EBRD assessment.

${ }^{34}$ This impact concerns the time period under consideration. Nevertheless, we do not expect the impact of privatization to be permanent.
} 
Naturally, we are also aware of other variables that have exhibited a significant influence on capital market emergence and its functioning. These variables concern the overall economic development of the country, its stability, other available channels of financial intermediation, as well as the legal and institutional environment. However, due to the nature of our sample and the unavailability of a significant part of the necessary data for transition economies (at least for the time being), the inclusion of these factors would lead to serious difficulties in econometric estimations ${ }^{35}$. Therefore, we assume that all these characteristics are included in the country effect, which is accounted for by using appropriate country dummy variables. The following section explains how we actually estimate the different modifications of privatization effect on capital market development while accounting for the country characteristics as well.

\section{Methodology and estimation}

The data set we use constitutes an unbalanced panel with a very high degree of variability. This concerns all the main characteristics of the capital market indicators (see Table 2 above). Accordingly, we need to account for these characteristics of the data set in our estimation. In the analysis we perform a simple estimation procedure in order to explain the changes of capital market functioning indicators when controlling for mass privatization and country effects. Our null hypothesis thus states that mass privatization implemented in the transition countries did not effect the development of capital markets in these countries. The alternative claims that mass privatization has influenced capital market development. More specifically, we expect that it has exhibited a negative influence on their functioning. The formal model specification which accounts solely for the effect of privatization is the following:

$$
\text { market_ind }=\text { const }+\beta \cdot \text { priv_effect }+\varepsilon
$$

where the relevant group of variables are defined as follows:

\footnotetext{
${ }^{35}$ There would be an insufficient number of observations for such an estimation, plus an endogeneity problem could arise when using some economic variables as explanatory variables. Unfortunately, standard methods of dealing with this problem are very difficult to apply in the case of transition economies because it is practically impossible to find an appropriate instrument. And even if we were able to come up with some reasonable one, it is usually impossible to obtain reliable data for it. A twostage estimation would require even more variables, leading us straight into the data availability problem again.
} 
- market_ind stands for an indicator of capital market development (market capitalization, turnover ratio, value traded, new capital raised)

- priv_effect accounts for different effects of privatization on the capital market in the following way:

$$
\begin{aligned}
\text { priv_effect }_{+} & =\beta_{1} \cdot \text { priv } \\
& =\beta_{2} \cdot t \cdot \text { priv } \\
& =\beta_{3} \cdot \text { priv }+\beta_{4} \cdot t \cdot \text { priv } \\
& =\beta_{5} \cdot \text { priv__prim }+\beta_{6} \cdot \text { priv_sec } \\
& =\beta_{7} \cdot t \cdot \text { priv_prim }+\beta_{8} \cdot t \cdot \text { priv_sec }
\end{aligned}
$$

where:

- priv is a dummy variable that equals 1 if voucher privatization was implemented in a given country, and equals 0 if another privatization method was implemented;

- priv_prim is a dummy variable that equals 1 if mass privatization was the primary privatization method in a given country;

- priv_sec is a dummy variable for mass privatization being a secondary privatization method.

The first specification of privatization effect (1a) is a mass privatization dummy without trend. This is meant to uncover the average effect of mass privatization implementation on the capital market. Specification $1 b$ includes linear trend, as we anticipate the impact of privatization to evolve during the transition period. This is expected due to the consolidation of ownership structure of privatized companies following the actual privatization. This process took several years and, in the majority of cases, was intermediated by the capital market. Consequently, most of the trades that took place on the stock exchanges depended heavily on the privatization procedure and its progress. The third specification (1c) includes both dummy variables in order to investigate the interaction of the initial effect of privatization and its evolution over time as well. Then, specification 1d distinguishes between mass privatization as primary and secondary privatization method. Finally, $1 \mathrm{e}$ is a modification of specification 1d where linear trend is accounted for.

It has already been noted that since the implementation of mass privatization usually took several years, its impact on capital markets could not be observed in the 
same year the privatization started. Therefore all three privatization effect specifications are further estimated: 1 . without any lag $\left(\operatorname{priv}_{t}\right)$

$$
\begin{aligned}
& \text { 2. with one year lag }\left(\operatorname{priv}_{t+1}\right) \\
& \text { 3. with two year lag }\left(\operatorname{priv}_{t+2}\right)
\end{aligned}
$$

In order to obtain an even more accurate picture of mass privatization's impact, a country dummy is added to the above specification. Then the following model is estimated:

$$
\text { market_ind }=\text { const }+\alpha \cdot \text { country }+\beta \cdot \text { priv_effect }+\varepsilon
$$

where country stands for a country dummy variable, and the specification of the privatization effect is the same as in equation (1)

The estimation and testing are done in the framework of the analysis of variance. We estimate the effect of privatization on capital market development when considering privatization effect alone (equation 1) as well as the privatization and country effects together (equation 2). Different privatization dummy modifications that were introduced for the first equation are also estimated for equation 2. We control only for privatization and country effects at this stage, as our primary objective is first to uncover if the effect of privatization is present in the data, that is, if privatization has had any influence on capital market development in transition countries at all. Even though controlling for country effects may be considered too broad a variable, in fact it contains all the country specific characteristics we need to account for. Therefore this is a much more general indicator than using only certain selected economic variables. And in this way we can also avoid the problem of possible model misspecification, since especially in the case of transition countries it is difficult to identify those economic variables that are truly crucial for capital market development ${ }^{36}$.

\subsection{Results}

The outcome of our estimation is discussed according to the different capital market indicators that were used as dependent variables.

\footnotetext{
${ }^{36}$ Nevertheless, later on as more data from transition countries becomes available, we would like to conduct a similar analysis with specific economic variables that would seem to be crucial for capital market development. 


\section{- MARKET CAPITALIZATION TO GDP}

The results showing the influence of mass privatization on market capitalization as a percentage of GDP are provided in the following Table 3.

Table 3: Results of ANOVA for market capitalization to GDP as dependent variable, pooled data

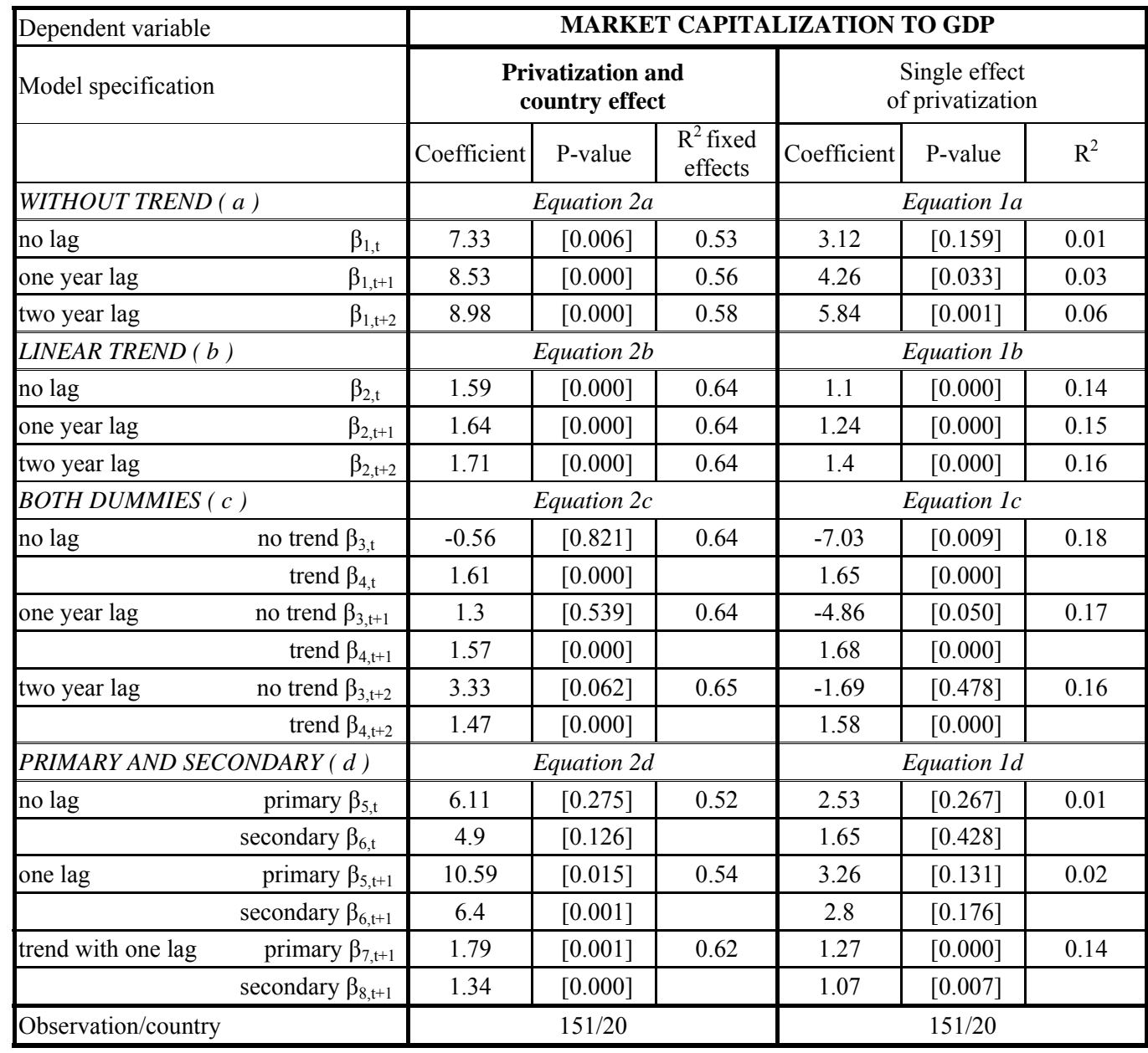

Note: The table contains two blocks: the right-hand side shows only the effect of privatization alone which is estimated based on the above-described equation 1 and its modifications. The lefthand side concerns the effect of privatization on market capitalization to GDP when country characteristics are also taken into account and the model is specified based on equation 2 . The privatization dummy variable equals one starting from the period when mass privatization was implemented in a given country. Both of the main equations are further estimated with different modifications of this privatization dummy variable: a) privatization dummy without trend, b) privatization dummy with linear trend, c) both privatization dummy variables with and without trend in one model specification, d) dummy variables for mass privatization as primary and secondary method of privatization (based on EBRD Transition Report). Moreover, dummy variables are in all cases considered without lag, then with one and two years lags as well. 
The table shows that country characteristics contribute a great deal to explaining the variability of the model. The $\mathrm{R}^{2}$ measure of the estimated model has improved from several percentage points to more than $60 \%$ when country characteristics are taken into account. This confirms our expectations, as the economic environment in individual transition economies tends to differ considerably, in particular with respect to the different initial conditions and different kind and sequence of reforms implemented. Using privatization dummies with different lags (up to two years) tends to provide more significant estimates, which in turn indicates that privatization did not fully influence the capital market right at the very beginning of its implementation. Lagging of dummy variables notably improves the estimation in cases when two privatization dummies are used in one estimation.

In the model specifications where single privatization dummies are used with as well as without country effects, their coefficients are positive and significant. This shows the positive influence of mass privatization on market capitalization. Nevertheless, the coefficients for dummies including linear trend are all significant, thus showing the evolving influence of mass privatization on capital market development. The significance of the privatization dummy without trend further indicates that there was a sudden change in market capitalization following implementation of the mass privatization scheme. As we expected, it was positive due to the fact that in the majority of countries the shares of privatized companies were simply put to the market.

We have also included both privatization dummies (with and without trend) in one model specification in order to investigate the initial effect and the effect on further development. Even though not all the coefficients turned out significant in this specification (most probably due to their possible correlation), there is a visible trend. When not taking country effects into account, the initial effect of mass privatization was negative. This could, however, be the trend of recovery rather than the actual immediate effect of mass privatization. Therefore we deemed it necessary to check the mean effect $^{37}$. The mean effect showed up positive and significant for all lags, which is in line with our expectations; it is thus possible to interpret the negative immediate impact as the trend of recovery. Country specifications have improved the model and consequently both with and without trend dummies exhibit positive coefficients

\footnotetext{
${ }^{37}$ In order to compute the mean effect we used the Delta method.
} 
consistent with our hypothesis. Nevertheless, in this case only the trend dummy remains significant and it seems that except for the case with a two-year lag, the dummy without trend adds no explanatory power.

When distinguishing the influence of mass privatization as primary and secondary method, the estimates become significant when accounting for linear trend and a lag, even if country characteristics are not considered. All in all, our expectations about the positive sign and significance of estimated coefficients when market capitalization serves as an explanatory variable were confirmed.

\section{- GROWTH IN STOCKS TRADED}

In line with our expectations, the impact of privatization on the growth in value of stocks traded is mostly significant when country characteristics are taken into account, even though, as the following Table 4 indicates, accounting for linear trend alone also provides significant estimates.

The estimation results show a significant effect of privatization not only for the linear trend privatization dummy but also when considering country characteristics together with both privatization dummies at once. When distinguishing primary and secondary mass privatization, only country effects together with trend and one year lag provide significant results. Despite most coefficients being significant, the $\mathrm{R}^{2}$ measure reaches only one third of the value for market capitalization. This points to the fact that the value of stocks traded was, in comparison to market capitalization, most probably influenced by privatization only indirectly, or that the actual privatization can be to certain extent correlated with the country effect. 
Table 4: Results of ANOVA for growth in value of stocks traded as dependent variable, pooled data

\begin{tabular}{|c|c|c|c|c|c|c|}
\hline \multirow{3}{*}{\begin{tabular}{|l} 
Dependent variable \\
Model specification
\end{tabular}} & \multicolumn{6}{|c|}{ GROWTH IN STOCKS TRADED, total value (\% of GDP) } \\
\hline & \multicolumn{3}{|c|}{ Privatization and country effect } & \multicolumn{3}{|c|}{ Single effect of privatization } \\
\hline & Coefficient & P-value & $\begin{array}{l}\mathrm{R}^{2} \text { fixed } \\
\text { effects }\end{array}$ & Coefficient & P-value & $\mathrm{R}^{2}$ \\
\hline WITHOUT TREND (a ) & \multicolumn{3}{|c|}{ Equation $2 a$} & \multicolumn{3}{|c|}{ Equation 1a } \\
\hline no lag & -0.55 & {$[0.153]$} & 0.19 & -1.46 & {$[0.249]$} & 0.04 \\
\hline one year lag & 0.40 & {$[0.200]$} & 0.19 & -1.11 & {$[0.321]$} & 0.03 \\
\hline two year lag & 0.18 & {$[0.603]$} & 0.19 & -1.01 & {$[0.328]$} & 0.02 \\
\hline LINEAR TREND $(b)$ & \multicolumn{3}{|c|}{ Equation $2 b$} & \multicolumn{3}{|c|}{ Equation $1 b$} \\
\hline no lag & -0.24 & {$[0.001]$} & 0.22 & -0.17 & {$[0.098]$} & 0.05 \\
\hline one year lag & -0.24 & {$[0.001]$} & 0.22 & -0.18 & {$[0.085]$} & 0.05 \\
\hline two year lag & -0.26 & {$[0.000]$} & 0.22 & -0.2 & {$[0.065]$} & 0.05 \\
\hline BOTH DUMMIES ( c ) & \multicolumn{3}{|c|}{ Equation 2c } & \multicolumn{3}{|c|}{ Equation 1c } \\
\hline no trend $\beta_{3, \mathrm{t}}$ & 0.29 & {$[0.558]$} & 0.22 & -0.59 & {$[0.658]$} & 0.05 \\
\hline trend $\beta_{4, \mathrm{t}}$ & -0.24 & {$[0.001]$} & & -0.12 & {$[0.016]$} & \\
\hline \multirow[t]{2}{*}{ one year lag } & 1.60 & {$[0.001]$} & 0.23 & 0.07 & {$[0.954]$} & 0.05 \\
\hline & -0.29 & {$[0.000]$} & & -0.19 & {$[0.001]$} & \\
\hline \multirow[t]{3}{*}{ two year lag } & 1.24 & {$[0.005]$} & 0.23 & 0.15 & {$[0.891]$} & 0.05 \\
\hline & -0.30 & {$[0.000]$} & & -0.21 & {$[0.000]$} & \\
\hline & \multicolumn{3}{|c|}{ Equation $2 d$} & \multicolumn{3}{|c|}{ Equation 1d } \\
\hline \multirow[t]{2}{*}{ no lag } & 2.57 & {$[0.236]$} & 0.20 & -0.59 & {$[0.528]$} & 0.02 \\
\hline & -0.55 & {$[0.155]$} & & -1.06 & {$[0.240]$} & \\
\hline \multirow[t]{2}{*}{ one lag } & 0.73 & {$[0.646]$} & 0.19 & -0.51 & {$[0.558]$} & 0.02 \\
\hline & 0.37 & {$[0.392]$} & & -0.87 & {$[0.311]$} & \\
\hline trend with one lag & -0.26 & {$[0.007]$} & 0.22 & -0.12 & {$[0.143]$} & 0.04 \\
\hline secondary $\beta_{8, t+1}$ & -0.26 & {$[0.032]$} & & -0.2 & {$[0.040]$} & \\
\hline Observation/country & & $102 / 17$ & & & $102 / 17$ & \\
\hline
\end{tabular}

Note: The table contains two blocks: the right-hand side shows only the effect of privatization alone which is estimated based on the above-described equation 1 and its modifications. The lefthand side concerns the effect of privatization on growth in value of stocks traded when country characteristics are also taken into account and the model is specified based on equation 2 . The privatization dummy variable equals one, starting from the period when mass privatization was implemented in a given country. Both of the main equations are further estimated with different modifications of this privatization dummy variable: a) privatization dummy without trend, b) privatization dummy with linear trend, c) both privatization dummy variables with and without trend in one model specification, d) dummy variables for mass privatization as primary and secondary method of privatization (based on EBRD Transition Report). Moreover, dummy variables are in all cases considered without lag, then with one and two years lags as well.

The immediate effect of privatization on trade is positive, as the introduction of such large amounts of new shares to the stock exchange leads to optimism and higher amounts of stocks traded. However, in the medium run, when the ownership structure consolidates and there is no more space for speculation of investment funds and other intermediaries, the influence of privatization becomes less positive. Thus trading, as an indicator of stock market liquidity which is crucial for healthy capital market 
development, is in fact negatively influenced by mass privatization and consequently standard capital market development is hindered. This trend is clear from the results for cases where we estimate the model including both privatization dummies (trend and without trend) at once and at the same time accounting for country effects. The negative long run effect is also reflected in significant results for the privatization dummy variable including linear trend; this is significant even without considering country effects, which once again supports our hypothesis about the long lasting influence of privatization. Yet even though this effect can be observed in the long run, we do not consider it permanent but rather only relevant to the transition period. The recent development of the stock indices for major transition countries also supports this statement (see Figure 1 in the appendix). It shows that despite the initial problems and costs related to them, market forces tend to win in the long run and to contribute to the stabilization of capital markets in the transition economies.

\section{- TURNOVER RATIO}

This is another indicator of capital market functioning that supports our previous results and the initial hypothesis. We consider the following outcome even more important, however, due to the better quality of the chosen turnover ratio indicator which is not spoiled by price changes or by a high number of listed companies after privatization, and which reflects the true liquidity of the market. The following Table 5 shows the estimation outcome.

The table shows that most of the estimated coefficients are significant, even for cases when country effects are not accounted for, the exception being cases where we consider two privatization dummy variables in one model. For privatization dummies with and without trend, the results are significant only when considering country effects. On the other hand, the outcome for mass privatization as the primary and secondary method is mixed; the only important result from our point of view is the significant negative coefficient for the primary privatization dummy variable when taking into account trend, one year lag, and country characteristics. Like the previous indicators of capital market development, here too the country characteristics have considerably improved the fit of the model when the $\mathrm{R}^{2}$ measure increased from several percentage points to as much as 40 percent. 
Table 5: Results of ANOVA for turnover ratio as dependent variable, pooled data

\begin{tabular}{|c|c|c|c|c|c|c|}
\hline \multirow{3}{*}{\begin{tabular}{|l} 
Dependent variable \\
Model specification
\end{tabular}} & \multicolumn{6}{|c|}{ TURNOVER RATIO } \\
\hline & \multicolumn{3}{|c|}{ Privatization and country effect } & \multicolumn{3}{|c|}{ Single effect of privatization } \\
\hline & Coefficient & P-value & $\begin{array}{l}\mathrm{R}^{2} \text { fixed } \\
\text { effects }\end{array}$ & Coefficient & P-value & $\mathrm{R}^{2}$ \\
\hline WITHOUT TREND ( a ) & \multicolumn{3}{|c|}{ Equation $2 a$} & \multicolumn{3}{|c|}{ Equation $1 a$} \\
\hline no lag & -61.24 & {$[0.013]$} & 0.41 & -41.43 & {$[0.040]$} & 0.10 \\
\hline one year lag & -45.89 & {$[0.020]$} & 0.40 & -37.72 & {$[0.043]$} & 0.09 \\
\hline two year lag & -45.48 & {$[0.001]$} & 0.41 & -35.77 & {$[0.031]$} & 0.09 \\
\hline LINEAR TREND $(b)$ & \multicolumn{3}{|c|}{ Equation $2 b$} & \multicolumn{3}{|c|}{ Equation $1 b$} \\
\hline no lag & -5.42 & {$[0.001]$} & 0.42 & -3.7 & {$[0.030]$} & 0.07 \\
\hline one year lag & -5.31 & {$[0.002]$} & 0.42 & -3.77 & {$[0.032]$} & 0.06 \\
\hline two year lag & -5.22 & [0.003] & 0.41 & -3.83 & {$[0.035]$} & 0.06 \\
\hline BOTH DUMMIES (c ) & \multicolumn{3}{|c|}{ Equation $2 c$} & \multicolumn{3}{|c|}{ Equation $1 c$} \\
\hline \multirow[t]{2}{*}{ no lag } & -41.87 & {$[0.082]$} & 0.44 & -32.25 & {$[0.151]$} & 0.10 \\
\hline & -4.22 & {$[0.009]$} & & -1.34 & {$[0.380]$} & \\
\hline \multirow[t]{2}{*}{ one year lag } & -28.71 & {$[0.135]$} & 0.43 & -29.2 & {$[0.158]$} & 0.09 \\
\hline & -4.32 & {$[0.011]$} & & -1.42 & {$[0.377]$} & \\
\hline \multirow[t]{2}{*}{ two year lag } & -32.26 & {$[0.022]$} & 0.43 & -30.02 & {$[0.105]$} & 0.09 \\
\hline & -3.91 & {$[0.028]$} & & -1.11 & {$[0.520]$} & \\
\hline PRIMARY AND SECONDARY $(d)$ & \multicolumn{3}{|c|}{ Equation $2 d$} & \multicolumn{3}{|c|}{ Equation 1d } \\
\hline \multirow[t]{2}{*}{ no lag } & -1.1 & [0.919] & 0.37 & -42.58 & {$[0.003]$} & 0.11 \\
\hline & -4.7 & {$[0.000]$} & & -28.48 & {$[0.064]$} & \\
\hline \multirow[t]{2}{*}{ one lag } & -10.65 & {$[0.216]$} & 0.37 & -41.32 & {$[0.003]$} & 0.10 \\
\hline & 0.04 & {$[0.990]$} & & -23.54 & {$[0.123]$} & \\
\hline \multirow{3}{*}{\begin{tabular}{|l} 
\\
Observation/country
\end{tabular}} & -2.93 & {$[0.026]$} & 0.39 & -3.84 & {$[0.005]$} & 0.06 \\
\hline & -5.06 & [0.118] & & -1.39 & {$[0.563]$} & \\
\hline & & $111 / 18$ & & & $111 / 18$ & \\
\hline
\end{tabular}

Note: The table contains two blocks: the right-hand side shows only the effect of privatization alone which is estimated based on the above-described equation 1 and its modifications. The left-hand side concerns the effect of privatization on turnover ratio when country characteristics are also taken into account and the model is specified based on equation 2 . The privatization dummy variable equals one starting from the period when mass privatization was implemented in a given country. Both of the main equations are further estimated with different modifications of this privatization dummy variable: a) privatization dummy without trend, b) privatization dummy with linear trend, c) both privatization dummy variables with and without trend in one model specification, d) dummy variables for mass privatization as primary and secondary method of privatization (based on EBRD Transition Report). Moreover, dummy variables are in all cases considered without lag, then with one and two years lags as well.

All the estimated coefficients concerning turnover ratio are negative, which only substantiates the unfavorable influence of privatization on capital markets. The negative effect holds true for both the initial effect and the influence evolving over time, since it is visible when both privatization dummies are considered in one model specification. 


\section{- NEW CAPITAL RAISED}

In comparison to turnover ratio, as the following Table 6 shows, the new capital raised variable in most cases does not provide us with significant parameters.

Table 6: Results of ANOVA for new capital raised as dependent variable, pooled data

\begin{tabular}{|c|c|c|c|c|c|c|}
\hline \multirow{3}{*}{$\begin{array}{l}\text { Dependent variable } \\
\text { Model specification }\end{array}$} & \multicolumn{6}{|c|}{ NEW CAPITAL RAISED (\% of market capitalization) } \\
\hline & \multicolumn{3}{|c|}{ Privatization and country effect } & \multicolumn{3}{|c|}{ Single effect of privatization } \\
\hline & Coefficient & P-value & $\begin{array}{l}\mathrm{R}^{2} \text { fixed } \\
\text { effects }\end{array}$ & Coefficient & P-value & $\mathrm{R}^{2}$ \\
\hline WITHOUT TREND ( a ) & \multicolumn{3}{|c|}{ Equation $2 a$} & \multicolumn{3}{|c|}{ Equation $1 a$} \\
\hline no lag & -0.010 & {$[0.113]$} & 0.31 & -0.001 & {$[0.480]$} & 0.01 \\
\hline one year lag & -0.020 & {$[0.045]$} & 0.67 & -0.004 & {$[0.154]$} & 0.11 \\
\hline two year lag & -0.010 & {$[0.125]$} & 0.38 & -0.003 & {$[0.162]$} & 0.08 \\
\hline LINEAR TREND ( $b$ ) & \multicolumn{3}{|c|}{ Equation $2 b$} & \multicolumn{3}{|c|}{ Equation $1 b$} \\
\hline no lag & -0.001 & {$[0.095]$} & 0.31 & -0.0003 & {$[0.154]$} & 0.05 \\
\hline one year lag & -0.001 & {$[0.118]$} & 0.30 & -0.0003 & {$[0.161]$} & 0.05 \\
\hline two year lag & -0.0004 & {$[0.143]$} & 0.28 & -0.0003 & {$[0.164]$} & 0.04 \\
\hline BOTH DUMMIES ( c ) & \multicolumn{3}{|c|}{ Equation $2 c$} & \multicolumn{3}{|c|}{ Equation 1c } \\
\hline \multirow[t]{2}{*}{ no lag } & -0.010 & {$[0.205]$} & 0.35 & 0.001 & {$[0.771]$} & 0.05 \\
\hline & -0.001 & {$[0.205]$} & & -0.0004 & {$[0.300]$} & \\
\hline \multirow[t]{2}{*}{ one year lag } & -0.020 & {$[0.047]$} & 0.67 & -0.004 & {$[0.159]$} & 0.11 \\
\hline & 0.000 & {$[0.982]$} & & 0.000 & {$[0.049]$} & \\
\hline \multirow[t]{2}{*}{ two year lag } & -0.010 & {$[0.131]$} & 0.38 & -0.003 & {$[0.168]$} & 0.08 \\
\hline & 0.000 & {$[0.561]$} & & 0.000 & {$[0.047]$} & \\
\hline PRIMARY AND SECONDARY $(d)$ & \multicolumn{3}{|c|}{ Equation $2 d$} & \multicolumn{3}{|c|}{ Equation 1d } \\
\hline \multirow[t]{2}{*}{ no lag } & -0.010 & {$[0.116]$} & 0.31 & -0.001 & {$[0.331]$} & 0.01 \\
\hline & -0.010 & {$[0.116]$} & & 0.000 & {$[0.983]$} & \\
\hline \multirow[t]{2}{*}{ one lag } & -0.030 & {$[0.000]$} & 0.92 & -0.003 & {$[0.171]$} & 0.06 \\
\hline & -0.030 & {$[0.000]$} & & -0.003 & {$[0.168]$} & \\
\hline \multirow[t]{3}{*}{ trend with one lag } & -0.0001 & {$[0.200]$} & 0.34 & -0.0002 & {$[0.172]$} & 0.04 \\
\hline & -0.001 & {$[0.107]$} & & -0.0003 & {$[0.169]$} & \\
\hline & & $81 / 14$ & & & $81 / 14$ & \\
\hline
\end{tabular}

Note: The table contains two blocks: the right-hand side shows only the effect of privatization alone which is estimated based on the above-described equation 1 and its modifications. The lefthand side concerns the effect of privatization on the new capital raised when country characteristics are also taken into account and the model is specified based on equation 2 . The privatization dummy variable equals one starting from the period when mass privatization was implemented in a given country. Both of the main equations are further estimated with different modifications of this privatization dummy variable: a) privatization dummy without trend, b) privatization dummy with linear trend, c) both privatization dummy variables with and without trend in one model specification, d) dummy variables for mass privatization as primary and secondary method of privatization (based on EBRD Transition Report). Moreover, dummy variables are in all cases considered without lag, then with one and two years lags as well.

Without considering country effects no coefficients are significant. Country effects similar to the previous estimation improve the situation, but only in a few cases. The best result is achieved for the privatization dummy without trend with one year lag. 
Here the one year lag most likely contributes significantly to an increase in the fit of the model and thus in a relatively small sample as we have, the $\mathrm{R}^{2}$ measure also increases substantially. This is most probably the case also for the one year lag dummy variable in the model where two privatization dummy variables are included. Moreover, the trend dummy without lag is also significant in showing the evolving influence of privatization. Despite these trends, the overall results for new capital raised seem to be quite ambiguous, possibly due to the unclear nature of the data on new capital raised, and to problems with its measurement in transition countries (discussed earlier in the data section). Another caveat is the relatively low number of observations, especially in comparison to other dependent variables that have been used. Some may even question the appropriateness of the new capital raised indicator for bank-based financial systems that traditionally tend to prevail in transition economies ${ }^{38}$. We are aware of these shortcomings, but nevertheless we consider the new capital raised variable very important to fulfilling the basic function of a capital market and thus it is included in our analysis as well.

In all of the above-described estimations, we have also included a dummy variable for the 1998 Russian crisis in order to check the robustness of our results. As the influence of the crisis on all transition countries was not that strong, however, this dummy did not figure significantly in our estimations.

Yet another modification of the basic model is the inclusion of a quadratic trend. We have considered a privatization dummy including quadratic trend alone as well as the interaction of it with privatization dummy without any trend component. The results have shown the same pattern as in the case of including linear trend, which once again points out the robustness of our results.

The simple estimation procedure performed above is, to our mind, appropriate with respect to the data sample we have available and with respect to the main objective of our investigation: uncovering if there is any connection between mass privatization and capital market development at all. Problems with sufficient amount of data occur if we want to include the development of capital markets over time, as an inseparable part of the transition process. In such a case we would need to add a trend for each country's development, yet this kind of estimation is not possible with such a small data sample as

\footnotetext{
${ }^{38}$ This issue has already been discussed in motivation part and based on this discussion capital market plays an important role also in bank-based financial systems.
} 
we have available now. Nevertheless, we believe that once more data is available, further research in this area is feasible.

\section{Conclusion}

We have used the available data from the majority of transition economies in order to prove the existence of a relationship between privatization method and the functioning of the capital market. The possible influence of privatization method on the capital market has been mentioned in the literature, but it has not been examined empirically. Thus, our main objective was to show, based on the available data, that this kind of connection in fact does exist in the transition countries. Our initial hypothesis stated that mass privatization has influenced capital market development and we have argued that it has exhibited a negative impact on capital market functioning. The results of our estimation, which accounted for privatization method as well as country effects, proved the validity of the hypothesis in the short and medium run. Moreover, the connection between mass privatization and capital market development was confirmed using different indicators of capital market development. In accordance with our expectations market capitalization to GDP increased suddenly following mass privatization. Yet despite this fact, the liquidity indicators confirmed that most of these shares were traded only occasionally or not at all, as the value of stocks traded as well as the turnover ratio exhibited negative coefficients concerning the privatization dummy. This trend became visible especially over the medium term.

These results further imply that in countries with mass privatization, the capital market was established and perceived only as a by-product of the privatization process and did not fulfill its main economic function of providing capital resources to enterprises. The non-transparent market, with thousands of securities established this way, led to a low level of investor confidence and did not contribute to initiating economic growth in transition economies. Despite such an unfavorable beginning, development of the main stock indexes in the transition economies has begun to show the improvement recently. Nevertheless, it seems that resources in the transition economies would have been used more efficiently if a more careful approach to capital market creation had been adopted. 


\section{References}

Ahdieh R.B. (2003): "Making Markets: Network Effects and the Role of Law in the Creation of Strong Securities Markets," Emory University, School of Law, Law and Economics Research Paper Series, No.2.

Bakker M., Gross A. (2004): "Development of Non-bank Financial Institutions and Capital Markets in European Union Accession Countries," World Bank Working Paper No. 28.

Beck T., Levine R. (2004): "Stock Market, Banks and Growth: Panel Evidence," Journal of Banking and Finance 28(3): 423 - 442.

Bennett J., Estrin S., Maw J., Urga G. (2004): "Privatization Methods and Economic Growth in Transition Economies," CEPR Discussion Paper No. 4291.

Berg A., Borensztein E., Sahay R., Zettelmeyer J. (1999): “The Evolution of Output in Transition Economies: Explaining the Differences," IMF Working Paper, WP/99/73.

Berglof E., Bolton P. (2003): "The Great Divide and Beyond - Financial Architecture in Transition," CEPR Discussion Paper No. 3476.

Biais B., Perotti E. (2002): "Machiavellian Privatization," American Economic Review 92(1): 240-258.

Bodin J., Wachtel P. (2002): "Financial Sector Development in Transition Economies: Lessons from the First Decade," Bank of Finland, Institute for Economies in Transition (BOFIT), DP No.9.

Brada J. (1996): "Privatization Is Transition - Or Is It?" Journal of Economic Perspectives 10: $67-86$.

Claessens S., Djankov S., Klingebiel D. (2000): "Stock Markets in Transition Economies," Financial Sector Discussion Paper No.5, The World Bank.

Claessens S., Lee R., Zechner J. (2003): "The Future of Stock Exchanges in European Union Accession Countries," CEPR report, published by the Corporation of London, available at http://www.cepr.org/pubs/fse/

Czech Republic: Capital Market Review (1999), The World Bank Washington, D.C.

De Melo M., Denizer C., Gelb A., and Tenev S. (1997): "Circumstances and Choice: The Role of Initial Conditions and Policies in Transition Economies", World Bank Policy Research Working Paper No. 1866.

Demirguc-Kunt A., Maksimovic V. (1998): "Law, Finance and Firm Growth," Journal of Finance 53(6): $2107-2137$. 
Davis E. P. (2001): "Multiple Avenues of Intermediation, Corporate Finance, and Financial Stability,” IMF Working Paper, WP/01/115.

Djankov S., Murrell P. (2002): "Enterprise Restructuring in Transition: A Quantitative Survey," Journal of Economic Literature 40(3): 739-792.

Estrin S., Stone R. (1997): “Taxonomy of Mass Privatization,” In Lieberman I., Stilpon N., Raj D. (Eds): Between State and Market: Mass Privatization in Transition Economies, The World Bank and OECD.

EBRD (European Bank for Reconstruction and Development), 1995 - 2004: Transition Report.

Falcetti E., Raiser M., Sanfey P. (2001): "Defying the Odds: Initial Conditions, Reforms and Growth in the First Decade of Transition," EBRD Working Paper No.55.

Fine G., Karlova E. (1998): "Privatization and the New Securities Markets in the Czech Republic, Poland and Russia," In Lieberman I., Kirkness Ch.: Privatization and Emerging Equity Markets, co-published by The World Bank and Flemings Washington, D.C.

Fischer S., Sahay R. (2000): “The Transition Economies After Ten Years," IMF Working Paper, WP/00/30.

Garcia Valeriano F., Giorgio Luis A. (2003): "The Impact of the Macroeconomic Environment on Capital Markets in Emerging Latin American Economies" In Dowers K., Masci P. (Eds.): "Focus on Capital: New Approaches to Developing Latin American Capital Markets," Inter-American Development Bank, Washington D.C.

Gupta N., Ham J., Švejnar J. (2000): "Priorities and Sequencing in Privatization: Theory and Evidence from the Czech Republic," William Davidson Institute Working Paper No. 323.

Hanousek J., Filer R. (2000): “The Relationship between Economic Factors and Equity Markets in Central Europe," Economics of Transition 8(3): 623 - 638.

Hanousek J., Kočenda E. (2003): "The Impact of Czech Mass Privatization on Corporate Governance," Journal of Economic Studies 30(3/4): 278-293.

Hanousek, J., Kočenda E., Švejnar J. (2004): “Ownership, Control and Corporate Performance After Large-Scale Privatization," William Davidson Institute Working Paper No. 652.

Hanousek J., Tůma Z. (1997): “A Test of the Permanent Income Hypothesis on Czech Voucher Privatization," CERGE-EI Working Paper 109.

Helmenstein Ch. (1999): Capital Markets in Central and Eastern Europe, Edward Elgar Publishing Limited, London. 
Henry P. B. (2000): "Stock Market Liberalization, Economic Reform, and Emerging Market Equity Prices,” Journal of Finance 55(2): 529 - 64.

King R., Levine R. (1993): "Finance and Growth: Schumpeter Might Be Right," Quarterly Journal of Economics 108(3): 717 - 738.

Kočenda E. (1999): "Residual State Property in the Czech Republic," Eastern European Economics 37(5): $6-35$.

Kočenda E., Švejnar J. (2003): "Ownership and Firm Performance after Large-Scale Privatization,” CERGE-EI Working Paper 209.

Kočenda E., Valachy J. (2002): "Firm Ownership Structures: Dynamic Development," Prague Economic Papers 11(3): 255 - 268.

Köke J., Schröder M. (2002): “The Prospects of Capital Markets in Central and Eastern Europe," Centre for European Economic Research (ZEW) Discussion Paper No. 02-57.

Korhonen I., Kuus T., Zirnask V. (2000): “Baltic Securities Markets,” Bank of Finland, Institute for Economies in Transition (BOFIT), DP No.5.

La Porta R., Lopez-de-Silanes F., Shleifer A., Vishny R. (1997): "Legal Determinants of External Finance," Journal of Finance 52(3): 1131 - 1150.

La Porta R., Lopez-de-Silanes F., Shleifer A., Vishny R. (1998): "Law and Finance," Journal of Political Economy 106(6): 1113 - 1155.

La Porta R., Lopez-de-Silanes F., Shleifer A., Vishny R. (2000): "Investor Protection and Corporate Governance," Journal of Financial Economics 58: 3 - 27.

Levine R., Zervos S. (1998): "Stock Markets, Banks, and Economic Growth," American Economic Review 88: 537 - 558.

Lízal L., Švejnar J. (2001): "Investment, Credit Rationing, and the Soft Budget Constraint: Evidence From Czech Panel Data," The Review of Economics and Statistics 84(2): $353-370$.

Pajuste A. (2002): "Corporate Governance and Stock Market Performance in Central and Eastern Europe: A Study of Nine Countries, 1994 - 2001," SSRN Electronic Journal, available at http://ssrn.com/abstract $=310419$

Pistor K., Raiser M., Gelfer S. (2000): "Law and Finance in Transition," Economics of Transition 8(2): $325-368$.

Roland G. (2001): “Ten Years After....Transition and Economics," IMF Staff Papers 48 , Special Issue. 
Rousseau P., Wachtel P. (2000): "Equity Markets and Growth: Cross-country Evidence on Timing and Outcomes, 1980 - 1995," Journal of Banking and Finance 24: 1933 1957.

Rozlucki W. (2001): "Emerging Stock Markets in Central Europe: Where Do We Stand?" In Bokros L., Fleming A., Votava C.: Financial Transition in Europe and Central Asia: Challenges of the New Decade, The International Bank for Reconstruction and Development / The World Bank.

Scholtens B. (2000): "Financial Regulation and Financial System Architecture in Central Europe," Journal of Banking and Finance 24: 525 - 553.

Simoneti M. (1997): "Regulating Post-privatization Securities Markets in Transition Economies," In Lieberman I., Stilpon N., Raj D. (Eds): Between State and Market: Mass Privatization in Transition Economies, The World Bank and OECD.

Stiglitz J. (1999): "Whither Reform? Ten Years of the Transition," Annual Bank Conference on Development Economics, Washington, World Bank.

Thimann Ch. (2002): "Financial Sectors in EU Accession Countries," European Central Bank.

Zinnes C., Eilat Y., Sachs J. (2001): "The Gains from Privatization in Transition Economies: Is ‘Change of Ownership' Enough?” IMF Staff Papers 48, Special Issue.

Wagner N., Iakova D. (2001): "Financial Sector Evolution in the Central European Economies: Challenges in Supporting Macroeconomic Stability and Sustainable Growth," IMF Working Paper 01/141.

World Bank (2002): "Transition. The First Ten Years: Analysis and Lessons for Eastern Europe and the Former Soviet Union, "Washington D. C.

World Bank Operations Evaluation Department (2004): "Economies in Transition: An OED Evaluation of World Bank Assistance," Conference Edition, The World Bank Washington D. C.

World Development Report 1996: "From Plan to Market," Oxford University Press 


\section{APPENDIX}

Table A.1: Number of observations for different variables and transition countries included in the analysis

\begin{tabular}{|c|c|c|c|c|c|c|}
\hline Country/variable & $\begin{array}{c}\text { Market } \\
\text { capitalization } \\
\text { to GDP }\end{array}$ & $\begin{array}{l}\text { Stocks } \\
\text { traded } \\
\text { growth }\end{array}$ & $\begin{array}{l}\text { Turnover } \\
\text { ratio }\end{array}$ & $\begin{array}{c}\text { New } \\
\text { capital } \\
\text { raised }\end{array}$ & $\begin{array}{c}\text { Mass } \\
\text { privatization } \\
\text { primary }\end{array}$ & $\begin{array}{c}\text { Mass } \\
\text { privatization } \\
\text { secondary }\end{array}$ \\
\hline Albania & $\mathrm{x}$ & $\mathrm{x}$ & $\mathrm{x}$ & $\mathrm{x}$ & $\mathrm{x}$ & 9 \\
\hline Armenia & 5 & $\mathrm{x}$ & 4 & $\mathrm{x}$ & 6 & $\mathrm{x}$ \\
\hline Azerbaijan & 2 & $\mathrm{x}$ & $\mathrm{x}$ & 2 & 4 & 3 \\
\hline Belarus & $\mathrm{x}$ & $\mathrm{x}$ & $\mathrm{x}$ & $\mathrm{x}$ & $\mathrm{x}$ & 10 \\
\hline $\begin{array}{l}\text { Bosnia and } \\
\text { Herzegovina }\end{array}$ & $\mathrm{x}$ & $\mathrm{x}$ & $\mathrm{x}$ & $\mathrm{x}$ & 4 & $\mathrm{x}$ \\
\hline Bulgaria & 8 & 4 & 4 & 7 & $\mathrm{x}$ & 8 \\
\hline Croatia & 8 & 7 & 7 & 2 & $\mathrm{x}$ & 6 \\
\hline Czech Republic & 10 & 9 & 9 & 9 & 12 & \\
\hline Estonia & 7 & 6 & 6 & 5 & $\mathrm{x}$ & 10 \\
\hline FYR Macedonia & 6 & 5 & 3 & $\mathrm{x}$ & $\mathrm{x}$ & $\mathrm{x}$ \\
\hline Georgia & $\mathrm{x}$ & $\mathrm{x}$ & 0 & $\mathrm{x}$ & 9 & $\mathrm{x}$ \\
\hline Hungary & 13 & 12 & 11 & 9 & $\mathrm{x}$ & $\mathrm{x}$ \\
\hline Kazakhstan & 5 & 3 & 3 & 2 & 5 & 5 \\
\hline Kyrgyz Republic & 2 & $\mathrm{x}$ & 1 & $\mathrm{x}$ & 10 & $\mathrm{x}$ \\
\hline Latvia & 8 & 5 & 7 & 6 & 6 & 5 \\
\hline Lithuania & 8 & 6 & 7 & 6 & 13 & $\mathrm{x}$ \\
\hline Moldova & 5 & 3 & 2 & $\mathrm{x}$ & 11 & $\mathrm{x}$ \\
\hline Poland & 12 & 9 & 12 & 9 & $\mathrm{x}$ & $\mathrm{x}$ \\
\hline Romania & 9 & 7 & 7 & 6 & $\mathrm{x}$ & 9 \\
\hline Russia & 12 & 9 & 8 & 2 & 12 & $\mathrm{x}$ \\
\hline Slovak Republic & 10 & 9 & 9 & 7 & $\mathrm{x}$ & 12 \\
\hline Slovenia & 10 & 1 & 6 & 9 & $\mathrm{x}$ & 10 \\
\hline Tajikistan & $\mathrm{x}$ & 0 & $\mathrm{x}$ & $\mathrm{x}$ & $\mathrm{x}$ & 2 \\
\hline Turkmenistan & $\mathrm{x}$ & 0 & $\mathrm{x}$ & $\mathrm{x}$ & $\mathrm{x}$ & $\mathrm{x}$ \\
\hline Ukraine & 7 & 5 & 5 & $\mathrm{x}$ & 9 & $\mathrm{x}$ \\
\hline Uzbekistan & 4 & 2 & $\mathrm{x}$ & $\mathrm{x}$ & $\mathrm{x}$ & $\mathrm{x}$ \\
\hline $\mathrm{Nb}$. of observations & 151 & 102 & 111 & 81 & 101 & 89 \\
\hline $\mathrm{Nb}$. of countries & 20 & 17 & 18 & 14 & 12 & 12 \\
\hline
\end{tabular}

Sources: WDI database, The World Federation of Exchanges, EBRD Transition Reports

Note: $\mathrm{x}$ indicates unavailability of data 
Table A.2: Primary and secondary privatization method implemented in transition countries

\begin{tabular}{|c|c|c|c|c|c|c|}
\hline \multirow{2}{*}{ Country } & \multicolumn{3}{|c|}{ Primary method } & \multicolumn{3}{|c|}{ Secondary method } \\
\hline & Direct sales & MEBOs & Vouchers & Direct sales & MEBOs & Vouchers \\
\hline Albania & & * & & & & * \\
\hline Armenia & $99 \rightarrow$ & & $\rightarrow 99$ & & $*$ & \\
\hline Azerbaijan $^{X}$ & $01 \rightarrow$ & & $*$ & $*$ & & $2001 \rightarrow$ \\
\hline Belarus & & $*$ & & & & * \\
\hline $\begin{array}{l}\text { Bosnia and } \\
\text { Herzegovina }\end{array}$ & & & $*(99 \rightarrow)$ & $*(99 \rightarrow)$ & & \\
\hline Bulgaria & $*$ & & & & & $*$ \\
\hline Croatia & & $*$ & & & & $*$ \\
\hline Czech Republic & & & $*$ & $*$ & & \\
\hline Estonia & $*$ & & & & & $*$ \\
\hline FYR Macedonia & & $*$ & & $*$ & & \\
\hline Georgia & & & * & $*$ & & \\
\hline Hungary & $*$ & & & & $*$ & \\
\hline Kazakstan & $99 \rightarrow$ & & $*$ & $*$ & & $99 \rightarrow$ \\
\hline Kyrgyz Republic & & & $*$ & & $*$ & \\
\hline Latvia & $99 \rightarrow$ & & $*$ & $*$ & & $99 \rightarrow$ \\
\hline Lithuania & & & $*$ & $*$ & & \\
\hline Moldova & & & $*$ & $*$ & & \\
\hline Poland & $*$ & & & & $*$ & \\
\hline Romania & & $*$ & & $*$ & & \\
\hline Russia & & & $*$ & $*$ & & \\
\hline $\begin{array}{l}\text { Serbia and } \\
\text { Montenegro }\end{array}$ & Serbia & & Monten. & $*$ & & \\
\hline Slovak Republic & $*$ & & & & & $*$ \\
\hline Slovenia & & $*$ & & & & $*$ \\
\hline Tajikistan & $99,2002 \rightarrow$ & 98,2001 & & 2000,2001 & $2002 \rightarrow$ & 98,99 \\
\hline Turkmenistan & & $*$ & & $*$ & & \\
\hline Ukraine & & & $*$ & & $*$ & \\
\hline Uzbekistan & & $*$ & & $*$ & & \\
\hline
\end{tabular}

Source: EBRD Transition Reports (1998 -2004)

Note: Data for Serbia and Montenegro are available only from 2003

$X$ - Direct sales in Azerbaijan took the form of cash auctions in 2000 and then were also used since 2002. 
Table A.3: Taxonomy of mass privatization

\begin{tabular}{|l|c|c|c|c|c|}
\hline Country & $\begin{array}{c}\text { Year voucher } \\
\text { distribution } \\
\text { began }\end{array}$ & $\begin{array}{c}\text { Shares issued } \\
\text { in waves - W or } \\
\text { continuously -C }\end{array}$ & Vouchers & $\begin{array}{c}\text { Investment } \\
\text { in funds }\end{array}$ & $\begin{array}{c}\text { Fund } \\
\text { management }\end{array}$ \\
\hline \hline Albania & 1995 & Continuously & Bearer & Encouraged & Independent \\
\hline Belarus & 1995 & Continuously & Bearer & Encouraged & Self-managed \\
\hline Russia & 1992 & Continuously & Bearer & Encouraged & Self-managed \\
\hline Armenia & 1994 & Continuously & Bearer & Allowed & Independent \\
\hline Kyrgyz Republic & 1994 & Continuously & Bearer & Allowed & Independent \\
\hline Estonia & 1993 & Continuously & Tradable & Allowed & Independent \\
\hline Georgia & 1995 & Continuously & Tradable & Allowed & Self-managed \\
\hline Latvia & 1994 & Continuously & Tradable & Allowed & \\
\hline Lithuania & 1993 & Continuously & Nontradable & Allowed & Independent \\
\hline Slovenia & 1994 & Continuously & Nontradable & Allowed & Independent \\
\hline Ukraine & 1995 & Continuously & Nontradable & Allowed & Self-managed \\
\hline Bulgaria & 1995 & Waves & Nontradable & Encouraged & Self-managed \\
\hline Czech Republic & 1992 & Waves & Nontradable & Encouraged & Independent \\
\hline Moldova & 1994 & Waves & Nontradable & Encouraged & Independent \\
\hline Slovak Republic & 1992 & Waves & Nontradable & Encouraged & Self-managed \\
\hline Kazakhstan & 1994 & Waves & Nontradable & Compulsory & Independent \\
\hline Poland & 1995 & Waves & Nontradable & Compulsory & Independent \\
\hline Romania & 1992 & Waves & Nontradable & Compulsory & Self-managed \\
\hline Romania & 1995 & Waves & Nontradable & Encouraged & \\
\hline
\end{tabular}

Source: Estrin S., Stone R. (1997): “Taxonomy of Mass Privatization,” In Lieberman I., Stilpon N., Raj D. (Eds): Between State and Market: Mass Privatization in Transition Economies, The World Bank and OECD. 
Table A.4: Models of mass privatization

\begin{tabular}{|c|c|c|}
\hline MODEL & Characteristics & $\begin{array}{c}\text { Other countries } \\
\text { following } \\
\text { the model }\end{array}$ \\
\hline Russian & $\begin{array}{c}\text { shares issued } \\
\text { continuously } \\
\text { bearer vouchers } \\
\text { funds encouraged }\end{array}$ & Belarus \\
\hline Armenian & $\begin{array}{c}\text { shares issued } \\
\text { continuously } \\
\text { bearer vouchers } \\
\text { funds allowed } \\
\end{array}$ & $\begin{array}{c}\text { Georgia }^{a} \\
\text { Kyrgyz Republic }\end{array}$ \\
\hline Lithuanian & \begin{tabular}{|c|} 
shares issued \\
continuously \\
nontradable vouchers \\
funds allowed \\
\end{tabular} & $\begin{array}{l}\text { Estonia }^{\mathrm{b}} \\
\text { Latvia }^{\mathrm{b}} \\
\text { Slovenia } \\
\text { Ukraine } \\
\end{array}$ \\
\hline Czech-Slovak & \begin{tabular}{|c} 
shares issued in waves \\
nontradable vouchers \\
funds encouraged
\end{tabular} & $\begin{array}{c}\text { Bulgaria } \\
\text { Moldova } \\
\text { Romania (1995) }\end{array}$ \\
\hline Polish & \begin{tabular}{|l} 
shares issued in waves \\
nontradable vouchers \\
funds compulsory
\end{tabular} & $\begin{array}{c}\text { Kazakhstan } \\
\text { Romania }(1992)^{c}\end{array}$ \\
\hline
\end{tabular}

Source: Estrin S., Stone R. (1997): “Taxonomy of Mass Privatization,” In Lieberman I., Stilpon N., Raj D. (Eds): Between State and Market: Mass Privatization in Transition Economies, The World Bank and OECD.

Notes:

a. it is not clear whether vouchers are bearer or registered

b. vouchers tradable for all or part of their validity

c. certificates of ownership in the funds were distributed in one wave but the exchange of the certificates for shares was on a continuous basis 
Table A.5: EBRD indicators of financial system reform for groups of transition countries

CENTRAL EASTERN EUROPE AND THE BALTICS (CEB)

\begin{tabular}{|c|c|c|c|c|c|c|c|c|c|c|}
\hline Country & EBRD index of & 1995 & 1996 & 1997 & 1998 & 1999 & 2000 & 2001 & 2002 & 2003 \\
\hline \multirow{2}{*}{$\begin{array}{l}\text { Czech } \\
\text { Republic }\end{array}$} & anking sector reform & 3.0 & 3.0 & 3.0 & 3.0 & 3.3 & 3.3 & 3.7 & 3.7 & 3.7 \\
\hline & $\begin{array}{l}\text { reform of non-bank financial } \\
\text { institutions }\end{array}$ & 2.7 & 2.7 & 2.7 & 3.0 & 3.0 & 3.0 & 3.0 & 3.0 & 3.0 \\
\hline \multirow[b]{2}{*}{ Estonia } & banking sector reform & 3.0 & 3.0 & 3.3 & 3.3 & 3.7 & 3.7 & 3.7 & 3.7 & 3.7 \\
\hline & \begin{tabular}{|l} 
reform of non-bank financial \\
institutions
\end{tabular} & 1.7 & 2.0 & 3.0 & 3.0 & 3.0 & 3.0 & 3.0 & 3.3 & 3.3 \\
\hline \multirow[b]{2}{*}{ Hungary } & banking sector reform & 3.0 & 3.0 & 4.0 & 4.0 & 4.0 & 4.0 & 4.0 & 4.0 & 4.0 \\
\hline & $\begin{array}{l}\text { reform of non-bank financial } \\
\text { institutions }\end{array}$ & 3.0 & 3.0 & 3.3 & 3.3 & 3.3 & 3.7 & 3.7 & 3.7 & 3.7 \\
\hline \multirow[b]{2}{*}{ Latvia } & banking sector reform & 3.0 & 3.0 & 3.0 & 2.7 & 3.0 & 3.0 & 3.3 & 3.7 & 3.7 \\
\hline & $\begin{array}{l}\text { reform of non-bank financial } \\
\text { institutions }\end{array}$ & 2.0 & 2.0 & 2.3 & 2.3 & 2.3 & 2.3 & 2.3 & 3.0 & 3.0 \\
\hline \multirow[b]{2}{*}{ Lithuania } & banking sector reform & 3.0 & 3.0 & 3.0 & 3.0 & 3.0 & 3.0 & 3.0 & 3.0 & 3.0 \\
\hline & $\begin{array}{l}\text { reform of non-bank financial } \\
\text { institutions }\end{array}$ & 2.0 & 2.0 & 2.3 & 2.3 & 2.7 & 3.0 & 3.0 & 3.0 & 3.0 \\
\hline \multirow{2}{*}{ Poland } & banking sector reform & 3.0 & 3.0 & 3.0 & 3.3 & 3.3 & 3.3 & 3.3 & 3.3 & 3.3 \\
\hline & $\begin{array}{l}\text { reform of non-bank financial } \\
\text { institutions }\end{array}$ & 3.0 & 3.0 & 3.3 & 3.3 & 3.3 & 3.7 & 3.7 & 3.7 & 3.7 \\
\hline \multirow{2}{*}{$\begin{array}{l}\text { Slovak } \\
\text { Republic }\end{array}$} & banking sector reform & 2.7 & 2.7 & 2.7 & 2.7 & 2.7 & 3.0 & 3.3 & 3.3 & 3.3 \\
\hline & $\begin{array}{l}\text { reform of non-bank financial } \\
\text { institutions }\end{array}$ & 2.7 & 2.7 & 2.3 & 2.3 & 2.3 & 2.3 & 2.3 & 2.3 & 2.7 \\
\hline \multirow{2}{*}{ Slovenia } & banking sector reform & 3.0 & 3.0 & 3.0 & 3.0 & 3.3 & 3.3 & 3.3 & 3.3 & 3.3 \\
\hline & $\begin{array}{l}\text { reform of non-bank financial } \\
\text { institutions }\end{array}$ & 2.7 & 2.7 & 2.7 & 2.7 & 2.7 & 2.7 & 2.7 & 2.7 & 2.7 \\
\hline
\end{tabular}

\section{SOUTH EAST EUROPE (SEE)}

\begin{tabular}{|c|c|c|c|c|c|c|c|c|c|c|}
\hline \multirow{2}{*}{ Albania } & banking sector reform & 2.0 & 2.0 & 2.0 & 2.0 & 2.0 & 2.3 & 2.3 & 2.3 & 2.3 \\
\hline & $\begin{array}{l}\text { reform of non-bank financial } \\
\text { institutions }\end{array}$ & 1.0 & 1.7 & 1.7 & 1.7 & 1.7 & 1.7 & 1.7 & 1.7 & 1.7 \\
\hline \multirow{2}{*}{$\begin{array}{l}\text { Bosnia and } \\
\text { Herzegovina }\end{array}$} & banking sector reform & 1.0 & 1.0 & 1.0 & 2.3 & 2.3 & 2.3 & 2.3 & 2.3 & 2.3 \\
\hline & $\begin{array}{l}\text { reform of non-bank financial } \\
\text { institutions }\end{array}$ & 1.0 & 1.0 & 1.0 & 1.0 & 1.0 & 1.0 & 1.0 & 1.7 & 1.7 \\
\hline \multirow{2}{*}{ Bulgaria } & banking sector reform & 2.0 & 2.0 & 2.7 & 2.7 & 2.7 & 3.0 & 3.0 & 3.3 & 3.3 \\
\hline & $\begin{array}{l}\text { reform of non-bank financial } \\
\text { institutions }\end{array}$ & 2.0 & 2.0 & 2.0 & 2.0 & 2.0 & 2.0 & 2.0 & 2.3 & 2.3 \\
\hline \multirow{2}{*}{ Croatia } & banking sector reform & 2.7 & 2.7 & 2.7 & 2.7 & 3.0 & 3.3 & 3.3 & 3.7 & 3.7 \\
\hline & $\begin{array}{l}\text { reform of non-bank financial } \\
\text { institutions }\end{array}$ & 2.0 & 2.0 & 2.3 & 2.3 & 2.3 & 2.3 & 2.3 & 2.7 & 2.7 \\
\hline \multirow{2}{*}{$\begin{array}{l}\text { FYR } \\
\text { Macedonia }\end{array}$} & banking sector reform & 3.0 & 3.0 & 3.0 & 3.0 & 3.0 & 3.0 & 3.0 & 3.0 & 3.0 \\
\hline & $\begin{array}{l}\text { reform of non-bank financial } \\
\text { institutions }\end{array}$ & 1.0 & 1.0 & 1.0 & 1.7 & 1.7 & 1.7 & 1.7 & 1.7 & 1.7 \\
\hline \multirow{2}{*}{ Romania } & banking sector reform & 3.0 & 3.0 & 2.7 & 2.3 & 2.7 & 2.7 & 2.7 & 2.7 & 2.7 \\
\hline & $\begin{array}{l}\text { reform of non-bank financial } \\
\text { institutions }\end{array}$ & 2.0 & 2.0 & 2.0 & 2.0 & 2.0 & 2.0 & 2.0 & 2.0 & 2.0 \\
\hline \multirow{2}{*}{$\begin{array}{l}\text { Serbia and } \\
\text { Montenegro }\end{array}$} & banking sector reform & 1.0 & 1.0 & 1.0 & 1.0 & 1.0 & 1.0 & 1.0 & 2.3 & 2.3 \\
\hline & $\begin{array}{l}\text { reform of non-bank financial } \\
\text { institutions }\end{array}$ & 1.0 & 1.0 & 1.0 & 1.0 & 1.0 & 1.0 & 1.0 & 1.7 & 2.0 \\
\hline
\end{tabular}


COMMONWEALTH OF INDEPENDENT COUNTRIES (CIS)

\begin{tabular}{|c|c|c|c|c|c|c|c|c|c|c|}
\hline Country & EBRD index of & 1995 & 1996 & 1997 & 1998 & 1999 & 2000 & 2001 & 2002 & 2003 \\
\hline \multirow[b]{2}{*}{ Armenia } & banking sector reform & 2.0 & 2.0 & 2.3 & 2.3 & 2.3 & 2.3 & 2.3 & 2.3 & 2.3 \\
\hline & $\begin{array}{l}\text { reform of non-bank } \\
\text { financial institutions }\end{array}$ & 1.0 & 1.0 & 1.0 & 2.0 & 2.0 & 2.0 & 2.0 & 2.0 & 2.0 \\
\hline \multirow{2}{*}{ Azerbaijan } & banking sector reform & 2.0 & 2.0 & 2.0 & 2.0 & 2.0 & 2.0 & 2.3 & 2.3 & 2.3 \\
\hline & $\begin{array}{l}\text { reform of non-bank } \\
\text { financial institutions }\end{array}$ & 1.0 & 1.0 & 1.0 & 1.7 & 1.7 & 1.7 & 1.7 & 1.7 & 1.7 \\
\hline \multirow[b]{2}{*}{ Belarus } & banking sector reform & 2.0 & 1.0 & 1.0 & 1.0 & 1.0 & 1.0 & 1.0 & 1.7 & 1.7 \\
\hline & $\begin{array}{l}\text { reform of non-bank } \\
\text { financial institutions }\end{array}$ & 2.0 & 2.0 & 2.0 & 2.0 & 2.0 & 2.0 & 2.0 & 2.0 & 2.0 \\
\hline \multirow{2}{*}{ Georgia } & banking sector reform & 2.0 & 2.0 & 2.3 & 2.3 & 2.3 & 2.3 & 2.3 & 2.3 & 2.3 \\
\hline & $\begin{array}{l}\text { reform of non-bank } \\
\text { financial institutions }\end{array}$ & 1.0 & 1.0 & 1.0 & 1.0 & 1.0 & 1.7 & 1.7 & 1.7 & 1.7 \\
\hline \multirow{2}{*}{ Kazakhstan } & banking sector reform & 2.0 & 2.0 & 2.3 & 2.3 & 2.3 & 2.3 & 2.7 & 2.7 & 3.0 \\
\hline & $\begin{array}{l}\text { reform of non-bank } \\
\text { financial institutions }\end{array}$ & 1.7 & 1.7 & 1.7 & 2.0 & 2.0 & 2.3 & 2.3 & 2.3 & 2.3 \\
\hline \multirow{2}{*}{$\begin{array}{l}\text { Kyrgyz } \\
\text { Republic }\end{array}$} & banking sector reform & 2.0 & 2.0 & 2.7 & 2.7 & 2.3 & 2.3 & 2.3 & 2.3 & 2.3 \\
\hline & $\begin{array}{l}\text { reform of non-bank } \\
\text { financial institutions }\end{array}$ & 1.7 & 2.0 & 2.0 & 2.0 & 2.0 & 2.0 & 2.0 & 2.0 & 2.0 \\
\hline \multirow[b]{2}{*}{ Moldova } & banking sector reform & 2.0 & 2.0 & 2.0 & 2.3 & 2.3 & 2.3 & 2.3 & 2.3 & 2.3 \\
\hline & $\begin{array}{l}\text { reform of non-bank } \\
\text { financial institutions }\end{array}$ & 2.0 & 2.0 & 2.0 & 2.0 & 2.0 & 2.0 & 2.0 & 2.0 & 2.0 \\
\hline \multirow[b]{2}{*}{ Russia } & banking sector reform & 2.0 & 2.0 & 2.3 & 2.0 & 1.7 & 1.7 & 1.7 & 2.0 & 2.0 \\
\hline & $\begin{array}{l}\text { reform of non-bank } \\
\text { financial institutions }\end{array}$ & 2.0 & 3.0 & 3.0 & 1.7 & 1.7 & 1.7 & 1.7 & 2.3 & 2.7 \\
\hline \multirow{2}{*}{ Tajikistan } & banking sector reform & 1.0 & 1.0 & 1.0 & 1.0 & 1.0 & 1.0 & 1.0 & 1.7 & 1.7 \\
\hline & $\begin{array}{l}\text { reform of non-bank } \\
\text { financial institutions }\end{array}$ & 1.0 & 1.0 & 1.0 & 1.0 & 1.0 & 1.0 & 1.0 & 1.0 & 1.0 \\
\hline \multirow{2}{*}{ Turkmenistan } & banking sector reform & 1.0 & 1.0 & 1.0 & 1.0 & 1.0 & 1.0 & 1.0 & 1.0 & 1.0 \\
\hline & $\begin{array}{l}\text { reform of non-bank } \\
\text { financial institutions }\end{array}$ & 1.0 & 1.0 & 1.0 & 1.0 & 1.0 & 1.0 & 1.0 & 1.0 & 1.0 \\
\hline \multirow[b]{2}{*}{ Ukraine } & banking sector reform & 2.0 & 2.0 & 2.0 & 2.0 & 2.0 & 2.0 & 2.0 & 2.3 & 2.3 \\
\hline & $\begin{array}{l}\text { reform of non-bank } \\
\text { financial institutions }\end{array}$ & 2.0 & 2.0 & 2.0 & 2.0 & 2.0 & 2.0 & 2.0 & 2.0 & 2.0 \\
\hline \multirow[b]{2}{*}{ Uzbekistan } & banking sector reform & 1.7 & 1.7 & 1.7 & 1.7 & 1.7 & 1.7 & 1.7 & 1.7 & 1.7 \\
\hline & $\begin{array}{l}\text { reform of non-bank } \\
\text { financial institutions }\end{array}$ & 2.0 & 2.0 & 2.0 & 2.0 & 2.0 & 2.0 & 2.0 & 2.0 & 2.0 \\
\hline
\end{tabular}

\section{Source: EBRD Transition reports}

Note: value 1 in both cases corresponds to little progress in the reform, value 4+ represents the standards and performance norms of advanced industrial economies. 
Figure 1: Development of stock market indices in some transition economies Czech Republic (index PX50)

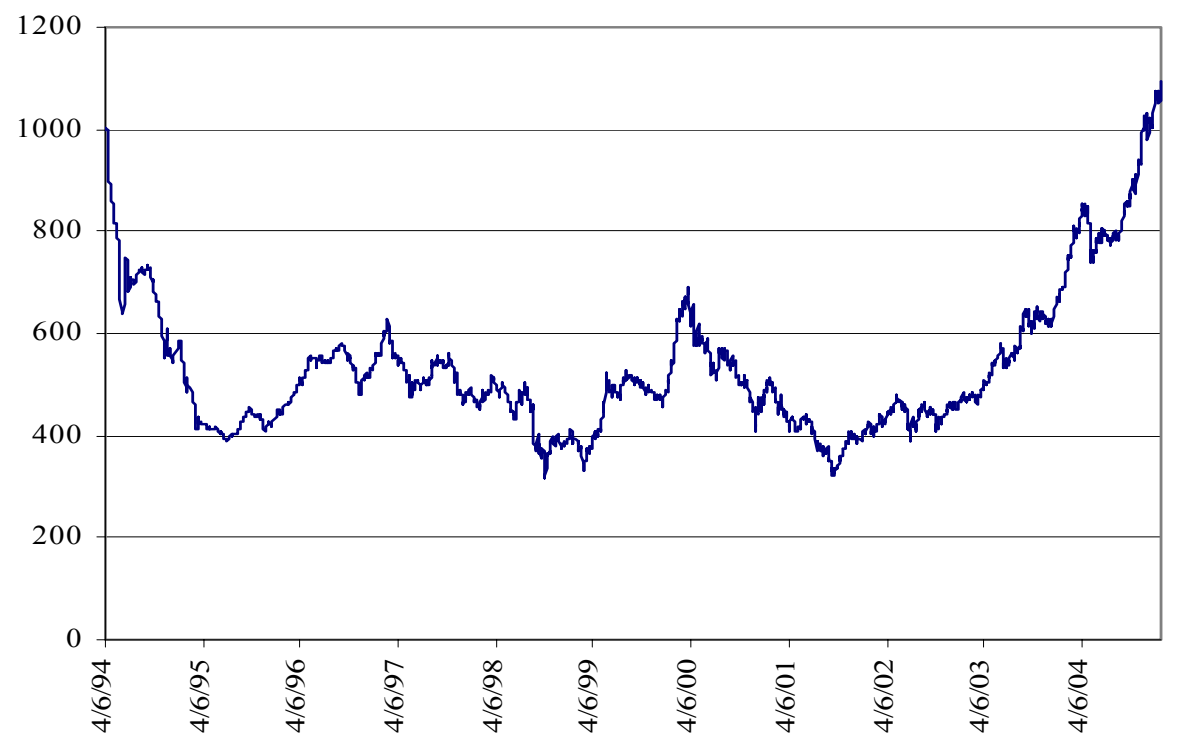

Slovak Republic (index SAX)

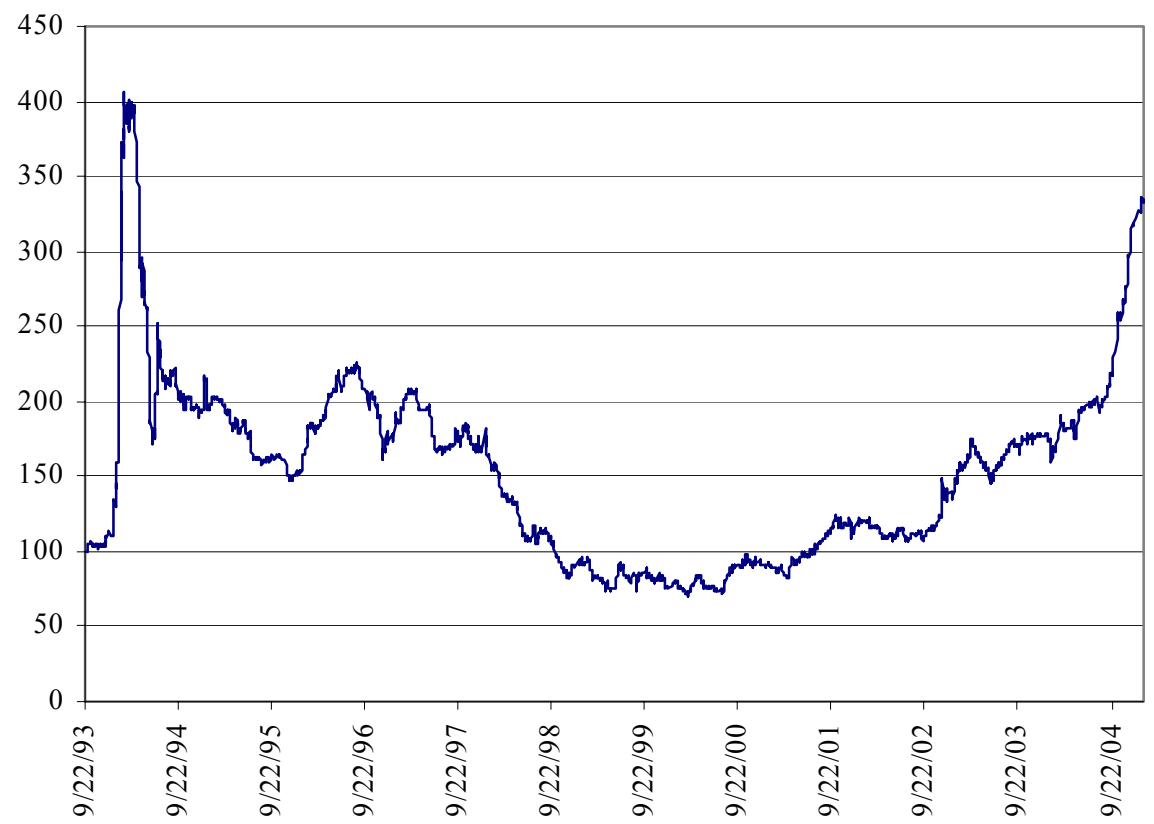




\section{Hungary (BUX index)}

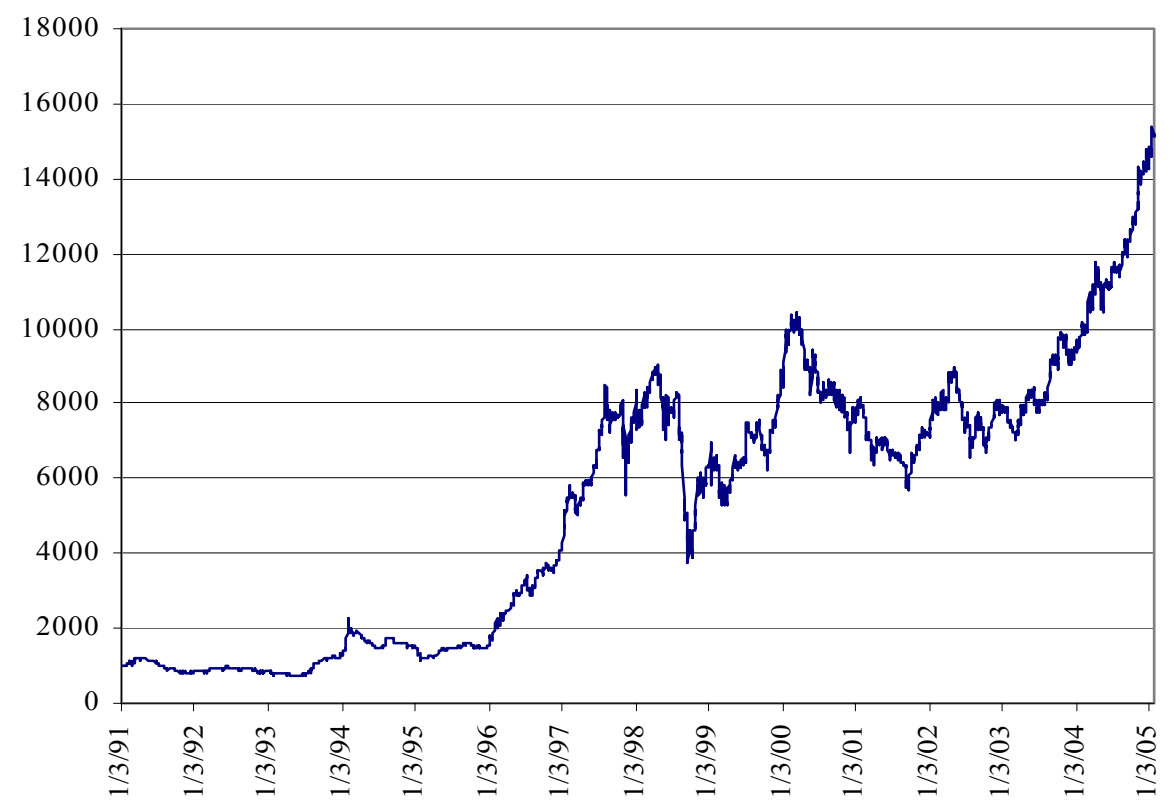

Source: Bloomberg 
Table A.6: Capital market development indicators of transition countries and their comparison with developed economies

\begin{tabular}{|l||c|c|c|}
\hline Country & $\begin{array}{c}\text { Market capitalization } \\
\text { to GDP }\end{array}$ & $\begin{array}{c}\text { Stocks traded } \\
\text { (\% of GDP) }\end{array}$ & Turnover ratio \\
\hline Armenia & 0.78 & na & 20.05 \\
\hline Azerbaijan & 0.08 & na & na \\
\hline Bulgaria & 3.52 & 0.45 & 9.51 \\
\hline Croatia & 16.74 & 0.77 & 4.17 \\
\hline Czech Republic & 22.36 & 8.27 & 36.94 \\
\hline Estonia & 30.43 & 9.99 & 27.46 \\
\hline FYR Macedonia & 0.73 & 0.65 & 119.74 \\
\hline Hungary & 16.05 & 10.11 & 51.25 \\
\hline Kazakhstan & 8.09 & 0.54 & 17.61 \\
\hline Kyrgyz Republic & 0.26 & na & 3.70 \\
\hline Latvia & 7.28 & 1.14 & 15.41 \\
\hline Lithuania & 12.88 & 1.36 & 20.18 \\
\hline Moldova & 7.28 & 2.93 & 51.85 \\
\hline Poland & 9.71 & 4.24 & 69.77 \\
\hline Romania & 3.55 & 0.59 & 41.69 \\
\hline Russia & 17.86 & 3.75 & 18.82 \\
\hline Serbia and Montenegro & 0.11 & 0.17 & na \\
\hline Slovak Republic & 6.33 & 4.65 & 99.89 \\
\hline Slovenia & 11.01 & 0.38 & 23.80 \\
\hline Ukraine & 5.47 & 0.41 & 5.93 \\
\hline Uzbekistan & 1.28 & 0.29 & na \\
\hline \hline Argentina & 27.70 & 3.70 & 23.19 \\
\hline Brazil & 25.65 & 11.59 & 42.49 \\
\hline EMU & 44.56 & 36.20 & 103.16 \\
\hline Germany & 36.04 & 36.42 & 134.25 \\
\hline Ireland & 63.21 & 25.62 & 54.56 \\
\hline Korea, Rep. & 41.90 & 74.10 & 168.67 \\
\hline Mexico & 27.12 & 9.16 & 34.22 \\
\hline United Kingdom & 131.69 & 70.42 & 129.93 \\
\hline United States & 105.90 & 124.12 & \\
\hline & & & \\
\hline
\end{tabular}

Note: All the numbers are averages of the available data for the period $1989-2003$

Source: WDI Database 
Table A.7: Definitions and data sources of the variables included in the analysis

\begin{tabular}{|l||l|l|}
\hline VARIABLE NAME & \multicolumn{1}{|c|}{ SOURCE } & \multicolumn{1}{c|}{ DEFINITION } \\
\hline \hline $\begin{array}{l}\text { Market capitalization } \\
\text { to GDP } \\
\text { (mcagdp) }\end{array}$ & $\begin{array}{l}\text { WDI database; } \\
\text { based on Standard \& } \\
\text { Poor's Emerging Stock } \\
\text { Markets Factbook }\end{array}$ & $\begin{array}{l}\text { the share price times the number of } \\
\text { shares outstanding } \\
\text { (\% of GDP) }\end{array}$ \\
\hline $\begin{array}{l}\text { Growth of value traded } \\
\text { trade_g) }\end{array}$ & $\begin{array}{l}\text { WDI database; } \\
\text { based on Standard \& } \\
\text { Poor's Emerging Stock } \\
\text { Markets Factbook }\end{array}$ & $\begin{array}{l}\text { value traded refers to the total value } \\
\text { of shares traded during the period } \\
\text { (\% of GDP) }\end{array}$ \\
\hline $\begin{array}{l}\text { Turnover ratio } \\
\text { turn) }\end{array}$ & $\begin{array}{l}\text { WDI database; } \\
\text { based on Standard \& } \\
\text { Poor's Emerging Stock } \\
\text { Markets Factbook }\end{array}$ & $\begin{array}{l}\text { total value of shares traded during the } \\
\text { period divided by the average market } \\
\text { capitalization for the period }\end{array}$ \\
\hline $\begin{array}{l}\text { New capital raised } \\
\text { capR_mc) }\end{array}$ & http://www.fibv.com \\
\hline $\begin{array}{l}\text { Mass privatization } \\
\text { dummy variable }\end{array}$ & $\begin{array}{l}\text { capital raised by all listed companies } \\
\text { (\% of market capitalization) }\end{array}$ \\
\hline
\end{tabular}


Individual researchers, as well as the on-line and printed versions of the CERGE-EI Working Papers (including their dissemination) were supported from the following institutional grants:

- Economic Aspects of EU and EMU Entry [Ekonomické aspekty vstupu do Evropské unie a Evropské měnové unie], No. AVOZ70850503, (2005-2010);

- Economic Impact of European Integration on the Czech Republic [Ekonomické dopady evropské integrace na ČR], No. MSM0021620846, (2005-2011);

Specific research support and/or other grants the researchers/publications benefited from are acknowledged at the beginning of the Paper.

(c) Zuzana Fungáčová, 2005

All rights reserved. No part of this publication may be reproduced, stored in a retrieval system or transmitted in any form or by any means, electronic, mechanical or photocopying, recording, or otherwise without the prior permission of the publisher.

Published by

Charles University in Prague, Center for Economic Research and Graduate Education (CERGE) and

Economics Institute (EI), Academy of Sciences of the Czech Republic

CERGE-El, Politických vězñu 7, 11121 Prague 1, tel.: +420 224005 153, Czech Republic.

Printed by CERGE-EI, Prague

Subscription: CERGE-El homepage: http://www.cerge-ei.cz

Editors: Directors of CERGE and EI

Managing editors: Deputy Directors for Research of CERGE and EI

ISSN 1211-3298

ISBN 80-7343-050-9 (Univerzita Karlova v Praze, CERGE)

ISBN 80-7344-039-3 (Národohospodářský ústav AV ČR, Praha) 
CERGE-EI

P.O.BOX 882

Politických vězňů 7

11121 Praha 1

Czech Republic http://www.cerge-ei.cz 